\title{
Volcano-Tectonic Earthquakes: a new tool for estimating intrusive volumes and forecasting eruptions
}

Randall White ${ }^{a}$ and Wendy McCausland ${ }^{b}$

a Volcano Disaster Assistance Program,

US Geological Survey,

345 Middlefield Road,

Menlo Park, California, USA 94025;

Tel: 650 3294746;

fax: 650 3295203; E-mail:

rwhite@usgs.gov

${ }^{b}$ Volcano Disaster Assistance Program,

US Geological Survey,

1300 SE Cardinal Court,

Vancouver, Washington, 98683-9589 


\begin{abstract}
:
We present data on 136 high-frequency earthquakes and swarms, termed volcano-tectonic (VT) seismicity, which preceded 111 eruptions at 83 volcanoes, plus data on VT swarms that preceded intrusions at 21 other volcanoes. We find that VT seismicity is usually the earliest reported seismic precursor for eruptions at volcanoes that have been dormant for decades or more, and precedes eruptions of all magma types from basaltic to rhyolitic and all explosivities from VEI 0 to ultraplinian VEI 6 at such previously long-dormant volcanoes. Because large eruptions occur most commonly during resumption of activity at longdormant volcanoes, VT seismicity is an important precursor for the Earth's most dangerous eruptions. VT seismicity precedes all explosive eruptions of VEI $\geq 5$ and most (all?) VEI 4 eruptions in our data set. Surprisingly we find that the VT seismicity originates at distal locations on tectonic fault structures at distances of a few to tens of kilometers laterally from the site of the eventual eruption, and rarely if ever starts beneath the eruption site itself. The distal VT swarms generally occur at depths almost equal to the horizontal distance of the swarm from the summit out to about $15 \mathrm{~km}$ distance, beyond which hypocenter depths level out. We summarize several important characteristics of this distal VT seismicity including: swarm-like nature, onset days to years prior to the beginning of magmatic eruptions, peaking of activity at the time of the initial eruption whether phreatic or magmatic, and large non-double couple component to focal mechanisms. Most importantly we show that the intruded magma volume can be simply estimated from the cumulative seismic moment of the VT seismicity from:
\end{abstract}

$\log _{10} V=0.71 \log _{10} \Sigma$ Moment -5.32, with volume, $V$, in cubic meters and seismic moment in Newton meters. Because the cumulative seismic moment can be approximated from the size of just the few largest events, and is quite insensitive to precise locations, the intruded magma volume can be quickly and easily estimated with few short-period seismic stations. 
Notable cases in which distal VT events preceded eruptions at long-dormant volcanoes include: Nevado del Ruiz (1984-1985), Pinatubo (1991), Unzen (1989-1995), Soufriere Hills (1995), Shishaldin (1989-1999), Tacana' (1985-1986), Pacaya (1980), Rabaul (1994),

Cotopaxi (2001). Additional cases are recognized at frequently active volcanoes including Popocateptl (2001-2003) and Mauna Loa (1984). We present four case studies (Pinatubo, Soufriere Hills, Unzen, and Tacana') in which we demonstrate the above mentioned VT characteristics prior to eruptions. Using regional data recorded by NEIC, we recognized in near-real time that a huge distal VT swarm was occurring, deduced that a proportionately huge magmatic intrusion was taking place beneath the long dormant Sulu Range, New Britain Island, Papua New Guinea, that it was likely to lead to eruptive activity, and warned Rabaul Volcano Observatory days before a phreatic eruption occurred. This confirms the value of this technique for eruption forecasting. We also present a counter-example where we deduced that a VT swarm at Volcan Cosiguina, Nicaragua, indicated a small intrusion, insufficient to reach the surface and erupt. Finally, we discuss limitations of the method and propose a mechanism by which this distal VT seismicity is triggered by magmatic intrusion.

Keywords: Volcano Seismology, Eruption Forecasting, Seismic Moment, Volcano Hazards, Precursory Seismicity, Volcano-Tectonic Earthquakes, Non-double couple 


\section{Introduction:}

The Volcano Disaster Assistance Program (VDAP) was formed by the US Geological Survey and the Office of Foreign Disaster Assistance following the disastrous eruption of Nevado del Ruiz, Colombia, in 1985. Since its inception, the VDAP team has helped build monitoring infrastructure in fourteen countries, responded to more than 25 volcanic crises worldwide, and had the opportunity to review tens of thousands of seismic records from those plus scores of additional eruptions and volcanic crises. One of the first phenomena the VDAP team noticed was that explosive eruptions are preceded by high-frequency volcano tectonic earthquakes that occur in swarm-like distributions and lack the typical main shockaftershock distribution of tectonic earthquake sequences. Further, we recognized that this VT seismicity originates at foci well away from the eventual eruption vent at lateral distances ranging from one or two to more than $30 \mathrm{~km}$. We call this "distal volcano tectonic" (distal VT or dVT) seismicity. To document and interpret this unusual seismicity, we have cataloged 75 cases where distal VT earthquake swarms have occurred prior to eruptions (Table 1), 37 more cases for which we infer that precursory seismicity was distal VT (Table 2), and 19 additional cases of distal VT seismicity during apparent magmatic intrusions (Table 3). Over the last 25 years, we have personally encountered more than 40 of these cases and have shown that distal VTs are related to magma intrusion and are invaluable for eruption forecasting (White and Power, 2001; White, 2006; White and Rowe, 2006).

In this paper we demonstrate the following characteristics of dVT earthquakes:

1. dVT's are often the earliest seismic precursor to eruptions at volcanoes that have been in repose for two decades or longer,

2. dVT's begin days to years prior to onset of eruptive activity, 
3. dVT's occur at offset distances ranging from less than $2 \mathrm{~km}$ to $45 \mathrm{~km}$ laterally from the eventual eruption site,

4. the dVT swarms occur at depths generally very similar to the offset distance of the swarm from the eventual eruption site to distances of $\sim 15 \mathrm{~km}$, beyond which the depths level out at $15-20 \mathrm{~km}$,

5. dVT earthquakes occur as swarms of events which generally increase in number and average energy over time where the largest events typically occur near or after the middle of the swarm and often include several events within $1 / 2$ magnitude unit of the largest event,

6. cumulative seismic moment of the dVT's is found empirically to be proportional to the intruded volume, in cases where that volume was determined independently.

We present four case studies to illustrate the above characteristics. We then present data from 75 eruptions at 61 volcanoes, each known to be have been preceded by dVT seismicity, the eruptions ranging in size and type from VEI 0 phreatic and/or passive basaltic extrusions to ultraplinian VEI 5 to 6 dacitic and rhyolitic eruptions. We discuss aspects of these data that are most useful for eruption forecasting and present three examples of how the VDAP team has used them in forecasting. Finally we suggest a mechanism driving the distal VT phenomenon which is compatible with the constraints presented in this paper.

\section{Methods:}

The data presented in this paper is in large part the result of examination of tens of thousands of paper seismograms and digital records of precursory seismicity conducted over the past 26 years during visits to volcano observatories around the world, including those in Mexico, Guatemala, El Salvador, Nicaragua, Costa Rica, Panama, Colombia, Ecuador, Peru, Chile, Montserrat, the Congo, Saudi Arabia, Indonesia, Papua New Guinea, Philippines, Japan, and Kamchatka, Russia (see Acknowledgements section for more details) 
as well as the U.S. Geological Survey's Alaska, Cascades, Hawaii, and California Volcano Observatories, and the Emergency Management Office of the Commonwealth of the Northern Mariana Islands. Additional data also come from hypocenter searches of the National Earthquake Information Center (NEIC) or International Seismic Center (ISC) worldwide seismic data bases, from the Smithsonian Institute's Global Volcanism Program reports and from published literature. The data for the Unzen case study come from Dr. Kodo Umakoshi.

Seismicity was classified into typical event types including low frequency (LF), hybrid, high frequency volcano tectonic (VT), tremor, explosion, and other surface flow events. Our definitions for these event types are consistent with definitions used by others (e.g. Lahr et al., 1994; Power et al., 1996; Chouet, 2003; and McNutt, 2005). In the cases where there were just paper records, events were classified by signal characteristics using the same station at distances less than $5 \mathrm{~km}$ where possible. Where digital data were available, events were classified using signal characteristics and spectral characteristics (e.g. bandwidth and dominant frequencies).

Network quality is variable for several reasons. In some cases the volcano was not recognized as potentially active and therefore the local network was installed after the onset of precursory activity (e.g. Chaiten, Pinatubo, and Kasatochi). In other cases remote location or lack of sufficient infrastructure prohibited the installation of more than one or two seismic stations. In such cases, events were located based on felt reports, S-P times and relative move-out across seismic stations. In cases with networks of more than 3 stations, events were located by local observatory personnel using P- and S-wave phases on at least 4 stations using standard location algorithms. In at least two cases, as we show for Soufriere Hills and Mt. Pinatubo, high precision relocation study results demonstrate that the preliminary locations are sufficient to determine whether events are distal or proximal.

Examples in the tables were compiled from seismic data sets directly examined by the authors, from published papers or reports, and/or from the Smithsonian Volcanoes of the World database (Siebert et al., 2010). Earthquake magnitudes are from observatory 
catalogs or the NEIC and ISC catalogues. For eruptions that pre-date reliable seismic reporting (before 1960), examples are from volcanoes with historical records of felt reports or where there were working seismometers (e.g. Sakurajima, 1914; Usu, 1910 and 1944; and Bezymianny, 1956). Volume changes are calculated from published data sources including modeled InSAR deformation (Sulu Range, Shishaldin, Akutan, and Peulik), deep well-injection records (e.g. Paradox Well, KTB Well, and Denver Well) which injections we propose trigger seismicity analogous to magma intrusion, modeled EDM deformation (Long Valley Caldera, Matsushiro, Yellowstone), and modeled magnetometer data (Poas).

\section{Case Studies:}

\subsection{Case study 1: Mt. Pinatubo, Philippines, 1991 VEI 6:}

The 1991 VEI 6 eruption of Mt. Pinatubo was the largest eruption worldwide during the last 100 years. Mt. Pinatubo was a relatively unknown, heavily forested 1745-m-high lava dome complex with no record of historical eruptions. Unrest near the volcano was first noticed when earthquakes began to be felt in Yamut and Tarao towns on 15 March, 1991 (Sabit et al., 1996), located about 5 to $6 \mathrm{~km}$ from the eruption vent on the west and northwest sides of Mt. Pinatubo. This seismicity increased in rate and intensity on the morning of April 2 and again shortly before the initial phreatic explosions about 1600 (local) that afternoon. We estimate that the largest felt events were about M4 to M4.5 based on the felt shaking reports. Local portable seismographs were installed three days later (Sabit et al., 1996) and the USGS and PHIVOLCS installed a permanent telemetered seismic network 5 weeks later (Harlow et al., 1996). The networks demonstrated that these earthquakes were occurring almost exclusively in that same area as the early felt reports, 5$6 \mathrm{~km} \mathrm{NW}$ of the summit and at depths of 5-6 km deep, and that they were generally 
decreasing in average rate of occurrence and average magnitude. An examination of the May seismograms shows that these were high-frequency dVT events. Figures $1 \mathrm{a}$ and $1 \mathrm{~b}$ show the relationship in map view and cross-section of the network locations for the dVT seismicity (blue) and the proximal seismicity (red). High-precision relocation of the distal VT swarm events (Jones et al., 2001) shows that the relocated dVT events occurred in a small volume and apparently define a NE-striking NW-dipping fault. The dVT locations and the continuing felt reports from Yamut and Tarao suggest that the prior felt events of midMarch to April 2 were also dVT events. There were no reports of felt events anywhere near the summit prior to April 2. Some proximal seismicity, in the form of long-period tremor and a few long period events (Sabit et al., 1996), was also recorded beneath the summit area as early as 5 April and we infer that this proximal, low-frequency seismicity began on April 2 with the initial phreatic explosions. Hybrid events began to occur beneath the summit on May 26 and increased with time until a dacite dome began to extrude late on 7 June and continued as the dome extruded. Plinian eruptions began on 12 June and the cataclysmic ultraplinian eruption occurred on 15 June during which up to $30 \mathrm{~km} 3$ of tephra (about $5 \mathrm{~km}^{3}$ dense rock equivalent) was explosively ejected (Koyaguchi, 1996).

[Figure 1 near here]

3.2 Case study 2: Soufriere Hills volcano, Montserrat, W.I., 1995-present, VEI 3.

Soufriere Hills Volcano, Montserrat, British West Indies, began erupting in 1995 and eventually produced several VEI 3 magmatic eruptions; see the special issues of Geophysical Research Letters 25 (18 and 19) (1998) and Druitt and Kokelaar (2002). This dominantly andesitic volcano has a summit area consisting primarily of a series of lava domes within a 
1-km-wide crater. A 17th-century eruption produced the Castle Peak lava dome but no subsequent eruptions were recorded on Montserrat until 1995 (Siebert et al., 2010). Volcanic seismicity during 1897-1900 and 1933-1937was strong enough to damage buildings and a period of much less and weaker volcanic seismicity occurred during 1966-67 (Miller et al. 1997).

Although the regional network was very sparse prior to late July 1995, the recent eruptive period apparently began with pulses of increasingly intense swarms of VT seismicity in January 1992, in January 1993, in 1994, in early 1995, then finally in June 1995 (Figure 2). These VTs reached M3.6 and the few locatable events had epicenters (Figure 2a) several to many kilometers northeast and northwest of the summit (epicentral errors are several kilometers). On seismograms, almost all events appear VT with impulsive onsets. Beginning on 14 July 1995 and peaking on 15 July, a strong ( M3.5) dVT swarm occurred and located just offshore to the east of Soufrière Hills volcano. On 18 July the first rather small phreatic eruption occurred at the summit. Further phreatic explosions from a second vent occurred on 28 July, the same day that the Seismic Research Institute installed a telemetered seismic network. On 5 August another dVT swarm began in a different location than the previous dVT swarm, 3-5 km ENE of the crater at 3-5 km depth. The dVT swarm started and increased in magnitude for 7 hours with largest events reaching M3.4, and then declined and was followed by increased LF tremor at the summit vents. On 12 August immediately after a phreatic explosion, another dVT swarm at a third location, 3-4 km WNW of the crater and 3$5 \mathrm{~km}$ deep, started and increased in magnitude for over 6 hours, with largest events reaching M4.0 before it declined. On 8 September another dVT swarm occurred at a fourth location, $4 \mathrm{~km}$ NNW of the crater and about $4 \mathrm{~km}$ deep, with largest events reaching M3.8. On 17 September yet another dVT swarm occurred at a new location, about $1 \mathrm{~km}$ to the east of the crater and 1-2 km deep with the largest events reaching M3.8. In each of these swarms, the largest events occurred after the middle of the swarm and there were at least 3 events within one-half of a magnitude unit of the largest event of the swarm. Focal 
mechanisms and relocations for the largest dVT's show double-couple mechanisms and indicate slip on pre-existing local faults. After September 17, the dVT's died off. Each of the dVT swarms correlated with activity from a different one of the four summit area phreatic vents and the swarms died off as each of the vents appeared to boil dry (Gardner and White, 2002). Hybrid-type seismicity then dominated as a dome emerged beginning on Sept. 25, 1995 (Gardner and White 2002). During the next several years seismicity was almost entirely of hybrid-type as dome lobes continued to be extruded and destroyed during collapse and/or vulcanian explosions (Baptie et al, 2002).

[Figure 2 near here]

\subsection{Case study 3: Unzen volcano (Mt. Fugen), Japan, 1991-1995, VEI 1:}

The massive Unzen volcanic complex comprises much of the Shimabara Peninsula, with historical dacitic eruptions restricted to the summit and flanks of Fugen-dake, the middle of three large stratovolcanoes with complex structures. The last previous eruptive activity was during the 1790's and formed a lava dome at the summit.

The largest overall dVT energy release occurred in 1984. According to Umakoshi et al. (2001), the first strong dVT seismicity occurred beginning in May 1984 beneath the western part of the Unzen Graben, and epicenters expanded westward into Tachibana Bay with time (Figure 3). The swarm peaked on 6 August 1984 with three main shocks with magnitudes M4.9, M5.3 and M4.8 (magnitudes from USGS-National Earthquake Information Center (NEIC) plus another event of similar magnitude, M5.1, on 19 October within Tachibana Bay (see Figure 3). This dVT seismicity occurred at least $12-15 \mathrm{~km}$ west of Unzen and continued 
sporadically at decreasing levels over 5 years until November 1989, when there was a significant resurgence in dVT swarms (largest magnitude 3.7) under Tachibana Bay (Umakoshi et al., 2001). The VT seismicity returned in 1989 and through May 1991 located 6-20 km west of the summit. Beginning in April, 1990 dVT seismicity became gradually stronger within the Shimabara Peninsula especially under the western flank of the volcano and on 7 July 1990 a dVT earthquake of M4.9 occurred coincident with the onset of tremor (Nakada et al, 1999). Distal VT seismicity ramped up and peaked at the time of the $1^{\text {st }}$ phreatic explosion in November 1990 then died off rapidly. It then ramped up again and peaked at the time of the $1^{\text {st }}$ phreatomagmatic eruption in February 1991, then decayed. Activity ramped up yet again and peaked in May, 1991 at the time of initial dome extrusion, after which the dVT seismicity died off for good, replaced largely by low-frequency (LF) earthquakes. Dacite dome extrusion began in May 1991 and lasted approximately 4 years. Once the dome appeared, the dVT earthquakes decreased dramatically and were replaced mainly by LF and a few VT events beneath the summit.

[Figure 3 near here]

\subsection{Case Study 4: Volcano Tacana', Guatemala and Mexico, 1986, VEI 1 phreatic eruption:}

Another case study from the VDAP archives provides an example from a very sparse network of only 3 vertical component short-period seismic stations. One of the earliest volcano crises for VDAP was associated with Tacana', a 4060-m-high composite stratovolcano on the border of Guatemala and Mexico with a summit dominated by a series of andesitic lava domes and having viscous lava flow complexes on the flanks. The last eruption previous to 1986 was in 1949-50. Figure 4a shows the distal VT swarm, which began 15 December 1985, was located 10-15 km ESE of Tacana'. The swarm peaked 19 
December with a M4.8 earthquake and then decreased greatly through January. Another pulse of distal VT seismicity then ramped up quickly in the same location peaking on 3 February with a M3.7 earthquake in the same area. Earthquakes continued through 7 February with rumbling heard by local residents at the base of the volcano. Low amplitude harmonic tremor began to appear on 8 February and strengthened the next day when a minor phreatic eruption occurred. More pulses of dVT energy release again occurred during 18-25 February and 2-10 March with events felt and heard by local residents. A final, large pulse of distal VT seismicity ramped up sharply on 7 May with events averaging 1 per minute accompanied by thunder-like noises for 23 hours. Inspected seismograms showed that these events were also from the same area as the previous VTs. On 8 May near noon (local time), a moderate phreatic explosion opened a 20-m-diameter vent. After the phreatic explosion all seismicity was very shallow, low frequency and located within $3 \mathrm{~km}$ of the vent. The seismicity decreased slowly through mid-June and was accompanied by the emission of a white steam plume which also decreased gradually from an initial height of $500 \mathrm{~m}$.

[Figure 4 near here]

\section{Synthesis}

The above four case studies illustrate that distal VT earthquakes are usually the earliest known precursor to eruptions at long dormant volcanoes. The seismicity began at least 7 weeks to 6 years before phreatic and 12 weeks before magmatic eruptions at locations 5 to $>15 \mathrm{~km}$ away laterally from the eruption vent at from one to several distinct locations. In each case the swarm locations were disconnected spatially from the LF/hybrid seismicity beneath the crater. The dVT s occurred in pulses of swarm-like seismicity that peaked in event rate and average 
magnitude about the time of the initial phreatic activity, of subsequent phreatic explosions and, at Soufriere Hills and Unzen, also just prior to the initial magmatic eruptions.

Although the above cases are all for eruptions at intermediate composition volcanoes, this pattern of precursory dVT's also occurs before eruptions of mafic composition, such as at Shishaldin, Alaska, and at Mauna Loa, Hawaii, and for silicic composition such as at Chaiten, Chile. At Shishaldin, a seismic network installed only months before the eruption recorded dVT seismicity including a M5.2 earthquake located 10-15 km west of Shishaldin Volcano on 4 March 1999 and a smaller swarm with magnitudes $M \leq 4.4$ at the same location on 13 April 1999, after which the volcano began to erupt, eventually producing a VEI 3 sub-Plinian basaltic-andesite eruption with a column to $16 \mathrm{~km}$ height (Moran et al., 2002).

After 25 years of quiescence, Mauna Loa, the world's largest volcano, produced voluminous but very passive VEI 0 eruptions in 1975 and 1984. The 1975 eruption was preceded by 16 months of precursory dVT seismicity at locations 5-8 km WNW, 3-5 km SW, 5-9 km NNW and 9-15 km WNW of the summit caldera, and at depths similar to those distances from the caldera center. Interestingly, dVT swarms again occurred prior to the 1984 eruption as noted by Lockwood et al. (1987): "The overall distribution of earthquakes in the 16 months before the eruption is remarkably similar to the distribution of earthquakes in the 16 months before the July 5, 1975 eruption."

In the case of the 2008 rhyolitic eruption of Chaiten, Chile, the onset was poorly recorded owing to no seismic stations within $250 \mathrm{~km}$. A temporary seismic network deployed in the area two years earlier recorded significant seismicity at Chaiten, possibly indicating that VT seismicity may have begun two or more years prior to the eruption (Lange et al. 2007). However precursory VT seismicity recorded from more than $250 \mathrm{~km}$ away began ramping 
up 2 days prior to the $1^{\text {st }}$ explosion, and increased to a peak (M5.3) two hours afterward. The two cataclysmic eruptions occurred 4 and 6 days later.

\section{5. dVT Database and Interpretations}

Where monitoring is adequate with at least 2 well-operating seismic stations (short-period is sufficient) within $10 \mathrm{~km}$ of the vent, the dVT seismicity almost always occurs as a swarm: it ramps up in both the event rate (as in Figure 5) and the average magnitude of events, thereby lacking the classic main shock-aftershock sequence characteristic of tectonic seismicity. This swarm-like character is well illustrated in Figure 5, which shows an example of seismicity leading to the Kasatochi eruption of 2008 (Ruppert et al., 2011). In hindsight, minor VT seismicity had begun a couple of weeks earlier, and then ramped up to the eruption in less than two days. Such behavior is typical of precursory dVT seismicity, for which the event rate and average event magnitude tend to increase with time and multiple events often have magnitudes within one-half magnitude unit of the largest event. This contrasts with tectonic seismicity, for which the largest event occurs at or very near the onset, is more than 1 magnitude unit larger than the next largest event, and the seismicity quickly dies down in event rate and magnitude with time.

[Figure 5 near here]

Table 1 provides examples of $98 \mathrm{dVT}$ swarms for 74 eruptions at 57 volcanoes where we have documented evidence for the pattern of precursory dVT seismicity described above. Table 2 presents data for an additional 38 eruptions at 26 volcanoes where we infer, from descriptions of the precursory seismicity, that those eruptions were very likely also 
preceded by this pattern of dVT seismicity. In the following analysis we shall focus mainly on the better documented data in Table 1.

[Table 1 near here]

[Table 2 near here]

Columns 2-4 of Table 1 show the onset date of dVT seismicity, the date of initial phreatic, or phreatomagmatic activity, and the date of initial magmatic eruptions where those dates are known. These data show that dVT seismicity generally preceded the magmatic eruptions by less than a day to several years, with the great majority beginning weeks to a few months before the eruption. All of the five highly explosive (VEI $\geq 5)$ eruptions in Table 1 occurred at volcanoes that had not erupted in at least 20 years. Consequently, we believe that dVT seismicity can provide a useful warning for such highly explosive eruptions. Including data from both Tables 1 and 2, we see that the VEI 5 magmatic eruptions at Bezymianny in 1955, Mount St. Helens in 1980, El Chichon' in 1982 and the VEI 6 eruption of Mount Pinatubo 1991 were all preceded by VT seismicity by a minimum of 10 weeks (see Tables 1 and 2 for references). A search of the ISC catalog, even though its reliability is restricted to earthquakes with magnitudes greater than 5 since 1955, and of the Global Volcanism Program database, shows that there have been at least 27 of 35 eruptions of VEI 4 and greater (Siebert et al., 2010) that were preceded by significant seismicity, including all eruptions of VEI 5 and VEI 6 . At the volcanoes that hadn't erupted during the previous 20 years, the eruptions for at least 11 of 14 volcanoes, and probably all of them, were preceded by significant VT seismicity; the remaining three volcanoes had no local seismic stations to detect possible dVT seismicity. 
It appears that an eruption at a volcano dormant for more than 25 years (see column 6, Table 1) is always preceded by significant dVT seismicity. However, dVT seismicity sometimes precedes eruptions at more frequently active volcanoes. For instance there are at least eight eruptions of VEI 4 since 1955 at volcanoes with less than 20 years eruptive quiescence that were preceded by significant dVT seismicity. More often though, the more frequently active a volcano is, the briefer and less energetic are the precursory dVT $\operatorname{swarm}(\mathrm{s})$.

Column 9, Table 1, shows the known depth (where known) and offset and azimuth of the center of the hypocentral clusters of the dVT swarms with respect to the eventual eruption sites. Offset values for dVT swarms range from 1-2 to 45 kilometers from the eventual eruption site, with $60 \%$ of 94 fairly well constrained values ranging from 2 to 8 kilometers away and $84 \%$ from 2-15 km away. The depths of dVT swarms are remarkably similar to the distances of the swarms from the eventual eruption site out to about 15 kilometers, beyond which the depths level out at roughly 15 kilometers (Figure 6). From this we infer that the dVT seismicity originates near the base of the brittle crust which is known to be thin beneath volcanoes but descends to roughly 15 to 20 kilometers deep elsewhere in arcs (Ito, 1993).

[Figure 6 near here]

The locations and focal mechanisms of dVT's where available often indicate that they originate on local tectonic faults where such faults have been extensively mapped. For example, prior to the VEI 3 eruption of Guagua Pichincha, Ecuador in 1999, dVT seismicity occurred for more than a year on a pre-existing splay of the Romeral Fault Zone about 15 $\mathrm{km}$ away from the volcano (Roman, De Angelis et al. 2008). The dVT's waxed and waned in 
close relationship to the phreatic activity at the volcano, peaking at the time of the first phreatic explosion and at times of subsequent phreatic explosions, yet the dVT hypocenters never approached to the volcano as the time of the eruption approached. The 2008 eruption of Nevado del Huila, Colombia was preceded by distal VT seismicity NNE and SSW of the summit along the Cauca-Romeral Fault Zone (Cardona, Santacoloma et al. 2009), (Chicangana, 2005). The general lack of migration of dVT events toward vents, the association with nearby fault zones, and lack of geographic connection to proximal seismicity and eruption vent are indicative of triggering of seismicity by aqueous fluid, as will be discussed in a later section.

Column 7, Table 1, shows the magnitude of the largest earthquake in each dVT swarm. We see that eruptions of VEI $>4$ are almost always preceded by a dVT of at least magnitude 3.9 and rarely as large as M6.7-7 (at Sakurajima, 1914). The largest dVT prior to less explosive eruptions may range anywhere from less than $\mathrm{M} \sim 3$ to the M6.7 prior to the Mauna Loa eruption of 1984 and possibly even as large as the M7.5-M8 near Mauna Loa in 1868.

\section{Cumulative dVT moment as proxy for intruded magma volume:}

Along with the early eruption warnings that distal VT's can provide, another useful characteristic of distal VT's is that the cumulative seismic moment $\Sigma \mathrm{M}_{\mathrm{o}}$ is proportional to the intruded magma volume. Column 9 of Table 1 shows the estimated $\Sigma M_{\circ}$ for precursory VT swarms. McGarr (1976) presented evidence that the $\Sigma M_{\circ}$ is proportional to a cumulative volume change such as associated with forcibly injecting water into deep well holes. We find that, where intruded magma volume at volcanoes can be estimated from deformation data, those data fit the McGarr relationship. Table 3 and Figure 7 show the $\Sigma M_{\circ}$ and the 
volume change for deep well injections (McGarr, 2014) and for magmatic intrusions. We find that the intruded magma volume can be simply estimated from the $\Sigma$ Magnitude and $\Sigma \mathrm{M}_{\mathrm{o}}$ of VT seismicity as follows: We use magnitudes published by ISC or NEIC where available (generally for larger events only), and otherwise use magnitudes published by individual observatories, often calculated from event durations. We assume that the magnitudes are within a factor of two of moment magnitudes. We convert the values of the largest events to seismic moment with $\log _{10} \Sigma$ Moment $=16.1+(3 / 2) \Sigma$ Magnitude from Hanks and Kanamori (1978). Then we sum these moments to get $\Sigma M_{0}$ and the corresponding cumulative magnitude for a single VT earthquake having the cumulative energy for all VT events in the swarm combined.

Then we relate this to intruded magma volume from Figure 7 using the best-fit line:

$\log 10 \mathrm{~V}=0.71 \log \Sigma$ Moment $_{\mathrm{o}}-\mathbf{5 . 3 2}$, with the volume change $\mathrm{V}$ in cubic meters and seismic moment in Newton meters.

[Figure 7 near here]

[Table 3 near here]

Because $\Sigma \mathrm{M}_{\mathrm{o}}$ is so heavily dominated by the few largest events, it can be closely approximated by simply summing the moment of those few events within $1 / 2$ magnitude unit of the largest event. That value is generally about double the value of the moment for the largest event as found by comparing formulas 7 and 11 of McGarr, (2014) for $b$ 1 of the Gutenberg-Richter relationship, as is generally the case for VT and well injection seismicity. Secondly, magnitude and moment calculations sometimes include a factor for the stationto-source distance, but for the near-source stations of volcano networks, that factor is negligible. Also note that our formula relies on the $\Sigma \mathrm{M}_{\mathrm{o}} \mathrm{c}$ for distal VTs only; however, as mentioned above, distal VT seismicity swamps proximal VT seismicity by an order of magnitude or more. In fact for closed systems with only minor or no fumarolic activity, the 
distal VT seismicity prior to onset of phreatic explosions dwarfs all precursory proximal seismicity, both VT and LF, so it is not necessary to separate distal from proximal VT seismicity, nor VT from LF seismicity. A sufficient approximation of intruded volume can be estimated by simply summing the seismic moment for all seismicity prior to phreatic onset. After phreatic onset, one simply sums all VT seismicity

For the reasons just stated, the $\Sigma$ Moment for VTs can be estimated from the magnitude of the few largest events recorded by just a single local well-calibrated short-period vertical component seismograph regardless of the location of the VTs, assuming S-P intervals $\leq 3$ sec, i.e. the VT events are within roughly $20 \mathrm{~km}$ of the station. Consequently and fortunately, it is possible to approximate intruded volume at volcanoes with only minimal seismic networks, the situation at many of the world's long-dormant volcanoes. However, it is more precise to estimate the magnitude and to identify dVT swarms using data from multiple stations at different azimuths.

Because the $\Sigma$ Moment is proportional to cumulative intruded volume, we may infer that small cumulative moments result from small intrusions that are likely to stall before reaching the surface. Table 4 lists 21 examples where dVT swarms occurred near or beneath the flanks of volcanoes without an immediately subsequent eruption but the swarms were accompanied by inflation, magmatic gas emissions and/or high temperatures, indicating that they were caused by magmatic intrusions.

[Table 4 near here]

\section{Application of these dVT observations to eruption forecasting:}


7.1 Case study 5: Forecast of volcanic activity at Sulu Range, New Britain Island, Papua New Guinea:

On the assumption that some minimum magma volume is required to rise from a magmatic storage region at $5 \mathrm{~km}$ or more depth to the surface for long dormant volcanoes, we have used this method of estimating the intruded volume to forecast several eruptions. Table 1 shows that for 28 of 30 eruptions at volcanoes dormant more than 20 years, dVT magnitudes rose to at least M3.7 prior to magmatic eruption and Table 2 lists another 42 of 44 apparently similar cases. We used the dVT to magma volume relation to issue an unusual eruption forecast, unusual in that the forecast was made based on teleseismic data recorded by NEIC. The intrusion volume estimated from the $\Sigma$ Moment at the Sulu Range was very large, later verified by InSAR (Wicks et al., 2007), and although no magmatic eruption occurred, the intrusion caused phreatic explosions from three locations. The Sulu Range consists of a cluster of partially overlapping small basaltic to rhyolitic stratovolcanoes and lava domes in north-central New Britain. No historical eruptions are known from the Sulu Range although some of the cones display a relatively undissected morphology.

On 6 July 2006, several earthquakes were first reported felt by residents in the Sulu range. Distal VT seismicity began to be recorded by NEIC the same day, with four earthquakes of M4.2- M4.5. On 9 July, additional and larger quakes of M4.8-M5.2 began to occur and by late 11 July, 15 quakes of M $\geq 4.5-M 5.3$ had occurred. With this dVT swarm characteristic of increasing numbers and magnitudes seen from the NEIC data, we alerted the Rabaul Volcano Observatory that a significant intrusion was underway. The moment centroid solutions for these events locate in the Sulu Range and west-northwest to the coast. Booming noises were heard at the Kaiamu and Silanga areas during felt earthquakes and vegetation was reported to having died off. Explosive emissions of mud and steam occurred from the Silanga Hot Springs, Mato Hot Springs, and Bakama Hot Springs. On 13 
to 15 July, a temporary seismograph station recorded continuous strings of high frequency earthquakes (including many that were felt) at rates as high as one event every 2 to 3 minutes. Moment centroids of the six largest events, of M5.1-M5.3, locate a few km offshore to the west-northwest. On July 19, a M6.4 event occurred further to the westnorthwest about $28 \mathrm{~km}$ from the Sulu range. This largest event of the dVT sequence was well recorded and the focal mechanism has a large non-double couple component of $39 \%$ and $61 \%$ double-couple component. This was followed a few hours later by a magnitude M5.9 quake $10 \mathrm{~km}$ even more distant to the west-northwest (along the dashed purple arrow in Figure 8a), after which the seismicity dropped off rapidly. By 24 July, 45 dVT's of $M \geq 4.5$ had occurred. Overall, the seismic moment release occurred in increasingly energetic pulses that peaked on 6, 9, 11, 16 and 19 July. The double couple component of the focal mechanisms show strike-slip with one plane striking west-northwest, strongly indicating that these events occurred along a west-northwest-striking strike-slip fault.

The seismic moment is dominated by the largest event, the M6.4, which together with combined energy of the thousands of smaller events, brings the total energy to the equivalent of one event of M6.5, the seismic moment of which correlates an intruded volume of nearly 200 million $\mathrm{m}^{3}$. Subsequently, an InSAR study by Wicks et al., (2007) demonstrated that approximately $1 \mathrm{~m}$ deformation occurred at and just west-northwest of the Sulu Range between the dates of 6 June and 22 July 2006, during which this seismic swarm occurred. Wicks estimated that the deformation correlates with an intruded volume of about 600 million $\mathrm{m} 3$, on the same order of magnitude as the value we estimated from the VT's recorded by NEIC stations thousands of kilometers away.

[Figure 8 near here] 


\subsection{Case study 6: Forecast of no eruption at Volcan Cosiguina, Nicaragua:}

In 2002 two earthquake swarms with the characteristics of dVT swarms occurred 4-6 km northwest of Cosiguina volcano, the northwestermost of Nicaraguan volcanoes. The swarms consisted of increasingly large events, with events increasing up to M3.5 during the first pulse of 4-6 September 2002, and increasing to M3.9 during the second pulse on 9-10 September (V. Tenorio, INETER, written communication, 2002). Six events had magnitudes within $1 / 2$ magnitude unit of the largest event of M3.9. During the swarm there were several smaller pulses of VT events spaced at 5.4 to 7.3 hour intervals. This pulsing of seismic energy over time would be highly unusual for tectonic seismicity but is quite common for distal VT swarms and very similar to the 7-10 hour intervals at Soufriere Hills. The cumulative seismic moment for the entire swarm correlates with a small intruded volume of 0.25 to 0.5 million $\mathrm{m}^{3}$ of magma. Given the lack of recent eruptions and very low level of unrest at Cosiguina, and our experience at similar volcanoes, we believed that it was unlikely that such a small intruded volume would reach the surface. Consequently, VDAP and INETER issued a forecast of no eruption unless there was were additional dVT swarms. Since then, nothing noteworthy has occurred there.

\section{Discussion and suggested mechanism for distal VT earthquakes:}

The compendium of field data suggests that, in addition to intrusions of magma, dVTs are commonly associated with: (1) an alignment along regional faults (Jones et al., 2001; Chicangana, 2005; Roman et al., 2008; Cardona et al., 2009; Legrand et al., 2009), (2) a lack of systematic migrations in dVT hypocenters with time and (3) non-double couple movements that involve local tension, as well as shear (e.g. Long Valley, 1980 and 1997 
(Ekstrom and Dziewonski, 1985; Julian and Sipkin, 1985; Kanamori et al., 1993; Foulger et al., 2004); Miyake-jima, 2000 (Minson et al., 2007); Sulu Range, 2006 (Section 7.1); Kasatochi, 2008 (Ruppert et al., 2011)). These features are consistent with the opening and slippage along faults following magma intrusion. The lack of migrating hypocenters suggests that the locations of dVTs do not follow a lateral migration of magma; instead, dVTs appear to reflect movements along faults following the intrusion of magma beneath the future location of eruption.

Although changes in the local stress field may trigger fault slip in the vicinity of an intrusion, it is unlikely that they can induce movements tens of kilometers away. Distant connections, however, could result from the propagation of high pore-fluid pressures along faults (Kanamori et al., 1993). Such a mechanism could also explain why dVT swarms tend to peak and die off at the time of the first significant phreatic activity. Whereas phreatic events are triggered by a build-up of high pore-fluid pressures, their occurrence allows the hydrothermal system to depressurize and to halt further phreatic activity until it has again become re-pressurized.

Based on theoretical stress-distributions at volcanoes, Hill (1977) argued that long-distance connections among aquifers could be established by meshes of parallel cracks around and beneath volcanoes, and evidence for such structures has subsequently been found at exhumed volcanic systems (Sibson, 1996). In addition, compared with the flow of magma through dykes or of aqueous fluids through permeable crust, it is physically easier to transmit a pressure pulse through an aquifer to distances of up 15-40 kilometers in the required time frame of hours. We therefore propose that dVT seismicity occurs when aquifers are over-pressurized by the intrusion of magma. Each pulse of intruding magma transmits pressure pulses through aquifers that intersect tectonically pre-stressed faults, thereby reducing the effective normal stress on those pre-stressed regional faults.

The proposed mechanism explains why the dVT phenomenon is ubiquitous at long-dormant volcanoes but uncommon at frequently active volcanoes. Thus, local faults that slipped significantly during dVT swarms before a recent eruption need time to become tectonically 
re-stressed, and aquifers which boiled off during a recent eruption are no longer confined and so need time to rehydrate and re-pressurize. The mechanism can also account for the following features of dVT seismicity:

(1) The occurrence of a large non-double-couple component, as well as double-couple slippage, to the focal mechanisms.

(2) The swarm-like nature of dVT seismicity and how it ramps up in numbers and magnitudes over weeks on a particular stretch of a fault: as magma slowly intrudes it would gradually over-pressurize an aquifer and so increasingly lubricate the local fault, allowing more and larger patches to slip.

(3) The occurrence of several main shocks produced by the continued intrusion of magma.

(4) The decay of dVTs on faults 15 to 40 kilometers away following depressurization of aquifers after initial phreatic explosions.

Although the cumulative dVT moment tells us about the volume of intruded magma, it is clear from Table 1 that this intruded volume does not tell us how explosive the eventual eruption will be. The eruptions of Mount Pinatubo and Mount St. Helens were preceded by dVT swarms consistent with only modest intruded volumes of 0.5-1 million m3 yet they were highly explosive in contrast the inferred intruded volumes at Long Valley and the Sulu Range were about 1000 times larger but did not lead to magmatic eruptions at all. Other factors such as magma viscosity, volatile content, caldera vs. stratovolcano, and ascent time are also important controls on explosivity. For instance, we do see indications where moderately small dVT swarms persisted over several years, such as at Soufriere Hills, Montserrat during 1992-1995, and at Nevado del Huila, Colombia during 2000-2008, apparently implying that magma ascent was very slow; thus the magma was mostly degassed by the time it reached the surface, and produced fairly passive extrusive eruptions. Similarly, at Unzen, by far the largest dVT swarm, with events of M4.9, M5.3, 
M4.8 and M5.1, occurred in 1984 over six years prior to extrusion, indicating that the bulk of the intrusion had been degassing for many years before finally reaching the surface during 1991 and producing a relatively passive eruption rather than a much more explosive eruption such as at Mount Pinatubo in 1991 or Mount St. Helens in 1980.

\section{Conclusions}

Based on our analysis of data for 111 eruptions at 83 volcanoes described here and summarized in Tables 1 and 2, we find that distal VT seismicity is generally the earliest recognized seismic precursor to eruptions at long dormant volcanoes, by which we mean volcanoes without an eruption for at least 25 years. This appears especially true for dVT activity preceding the most explosive eruptions of VEI 4 and greater. For long dormant volcanoes, we find that dVT seismicity precedes eruptions of all magma types from basaltic to rhyolitic and all explosivities from VEI 0 to ultraplinian VEI 6. We find that this distal VT seismicity appears to originate on tectonic fault structures offset anywhere from a few $\mathrm{km}$ to more than $30 \mathrm{~km}$ laterally from the site of the eventual eruption. The distal VT swarms generally occur at depths comparable to the horizontal distance of the swarm from the summit out to about $15 \mathrm{~km}$ distance, beyond which depths level out. We note several important characteristics of this distal VT seismicity including its swarm-like nature, beginning days to years prior to the onset of magmatic eruptions, generally peaking at the time of the initial phreatic or phreatomagmatic eruption and having a large volumetric opening component to focal mechanisms. Most importantly we find that the intruded magma volume can be simply estimated from the cumulative seismic moment of the VT seismicity using the empirical relation: $\log 10 \mathrm{dV}=0.71 \log \Sigma \mathrm{M}_{\mathbf{0}}-\mathbf{- 5 . 3 2}$, with volume $\mathrm{V}$ in cubic meters and moment $M_{0}$ in Newton meters. Because the cumulative seismic moment can be approximated from the size of the few largest events, and is insensitive to precise locations, the intruded magma volume can be quickly and easily estimated with but a few 
short-period seismic stations. We also document cases in which this knowledge has been used in forecasting an eruption (and the lack of an eruption). We propose a mechanism to account for the dVT phenomenon in which pulses of magma intruding over time transmit pressure pulses through aquifers that intersect tectonically pre-stressed faults, lubricating and opening such faults and thus generating swarms of dVT events with both double-couple and large, at least temporary, opening components in their focal mechanisms.

\section{Acknowledgments}

We wish to thank our many colleagues who have welcomed us and provided critical data for this paper, from the U.S. Geological Survey's Alaska, Cascades, Hawaii, and California Volcano Observatories, the Emergency Management Office of the Commonwealth of the Northern Mariana Islands, the National Center for the Prevention of Disasters (CENAPRED, Mexico), the University of Colima (Mexico), the National Autonomous University (UNAM, Mexico), the National Institute for Seismology, Volcanology, Hydrology and Meteorology (INSIVUMEH, Guatemala), the National Service tor Territorial Studies (SNET, El Salvador), the Nicaraguan Institute for Territorial Studies (INETER), the Volcano and Seismology Observatory of Costa Rica (OVSICORI), the Colombian Institute of Geology and Mining (INGEOMINAS), the Geophysical Institute of the National Polytechnic School (IGEPN, Ecuador), the National Geology and Mining Service of Chile (SERNAGEOMIN), the Montserrat Volcano Observatory (MVO, British West Indies), the Democratic Republic of the Congo, the Saudi Geological Survey, the Institute of Volcanology and Seismology (Russia), the Philippine Institute of Volcanology and Seismology (PHIVOLCS), the Rabaul Volcano Observatory, (Papua New Guinea), and the Center of Volcanology and Geological Hazard Mitigation (CVGHM, Indonesia). Additional data also come from hypocenter searches of the National Earthquake Information Center (NEIC) or International Seismic Center (ISC) 
worldwide seismic databases, from the Smithsonian Institute's Global Volcanism Program reports and from published literature. The data for the Unzen case study come from Dr. Kodo Umakoshi. The authors acknowledge long-term support to the Volcano Disaster Assistance Program from the

USAID-Office of Foreign Disaster Assistance, without which this work would not have been possible. Most of all we wish to recognize and thank the hardworking members of the VDAP team who have helped install seismometers and computers on volcanoes all over the world on at least 50 volcanoes since 1985 from which most of the data for this paper have come. We especially want to thank John Power and Chris Newhall for the early discussions that got this work started, Tom Murray for inventing the RSAM system which made much of this analysis much easier, Andy Lockhart for installing most of the seismic equipment and Jeff Marso for installing most of the computer equipment at so many of the foreign observatories. And we also wish to thank the VDAP Chief Scientist - Dr. John Pallister for his leadership and his excellent review and Dave Hill and two anonymous reviewers for their excellent reviews and suggestions that have significantly improved the manuscript. 
TABLE 1 Eruptions with known precursory distal volcano-tectonic (VT) earthquake swarms

\begin{tabular}{|c|c|c|c|c|c|c|c|c|c|c|c|}
\hline $\begin{array}{l}\text { Volcano } \\
\text { Name }\end{array}$ & $\begin{array}{l}\text { Date of } 1^{\text {st }} \\
\text { known } \\
\text { dVT events }\end{array}$ & $\begin{array}{l}\text { Date of 1st } \\
\text { Phreatic (P) } \\
\text { or Phreato- } \\
\text { magmatic } \\
\text { (PM) activity }\end{array}$ & $\begin{array}{l}\text { Date of } \\
\text { Magmatic } \\
\text { Eruption } \\
\text { onset }\end{array}$ & $\begin{array}{l}\text { V } \\
\mathrm{E} \\
\mathrm{I}\end{array}$ & $\begin{array}{l}\text { Years } \\
\text { since } \\
\text { prior } \\
\text { Erup- } \\
\text { tion }\end{array}$ & $\begin{array}{l}\text { Maxi- } \\
\text { mum } \\
\text { VT } \\
\text { Mag } \\
\text { ni- } \\
\text { tude }\end{array}$ & $\begin{array}{l}\text { Log10 } \\
\text { cumu- } \\
\text { lative } \\
\text { Mo- } \\
\text { ment } \\
\text { nm }\end{array}$ & \begin{tabular}{l|}
$D$ \\
$e$ \\
$p$ \\
$t$ \\
$h$ \\
km
\end{tabular} & $\begin{array}{l}\text { D } \\
\text { i } \\
\text { s } \\
\text { t. } \\
\text { km }\end{array}$ & $\begin{array}{l}\text { Azi- } \\
\text { muth }\end{array}$ & References \\
\hline Anatahan & $\leq 20030506$ & 20030510 PM & 20030510 & 3 & $>400$ & M4.1 & 15.4 & $\begin{array}{l}3 \\
3\end{array}$ & $\begin{array}{l}2.5 \\
3\end{array}$ & $\begin{array}{l}\mathrm{N} \\
\text { SW }\end{array}$ & This study, (Pozgay, 2005) \\
\hline Augustine & 200504 & $20051220 \mathrm{P}$ & 20060111 & 3 & 20 & M3.7 & 15.0 & $\begin{array}{l}14 \\
1\end{array}$ & $\begin{array}{c}25 \\
1\end{array}$ & $\begin{array}{l}\mathbf{E} \\
\mathbf{E}\end{array}$ & $\begin{array}{l}\text { AVO (Fisher, 2010; } \\
\text { Power, 1988) }\end{array}$ \\
\hline Augustine & 19850705 & $19860111 \mathrm{P}$ & 19860228 & $4 ?$ & 10 & M4.3 & 15.7 & 2 & 1 & E? & AVO (Power, 2010) \\
\hline Augustine & 19750502 & $19760122 \mathrm{P}$ & 19760123 & 4 & 5 & M3.5 & ?? & 2 & 1 & SE? & AVO (Power, 2010) \\
\hline Cerro Hudson & 20111025 & $20111026 \mathrm{P}$ & 20111027 & 3 & 20 & M5.0 & 16.6 & 9 & 9 & $\mathbf{W}$ & $\begin{array}{l}\text { (Hermosilla Pineda 2012) } \\
\text { SERNAGEOMIN }\end{array}$ \\
\hline $\begin{array}{l}\text { Cerro Negro } \\
\text { (Nicaragua) }\end{array}$ & 19950524 & $19950529 \mathrm{P}$ & 19951119 & 2 & 4 & M3.4 & 15.0 & $\begin{array}{l}\mathrm{Z} ? \\
\mathrm{Z} ?\end{array}$ & $\begin{array}{l}8 \\
5-10\end{array}$ & $\begin{array}{c}E \\
\text { NW }\end{array}$ & This study, INETER \\
\hline $\begin{array}{l}\text { Cerro Negro } \\
\text { (Nicaragua) }\end{array}$ & 19990223 & $19990508 \mathrm{P}$ & 19990805 & 2 & 4 & M5 & 17.2 & $\begin{array}{l}10 \\
8\end{array}$ & $\begin{array}{l}12 \\
8\end{array}$ & $\begin{array}{c}\mathrm{E} \\
\text { NW }\end{array}$ & $\begin{array}{l}\text { This study, INETER (La } \\
\text { Femina, 2004) }\end{array}$ \\
\hline Chaiten & $\leq 20080501$ & 20080502 PM & 20080506 & 5 & $\sim 400$ & M5.3 & 17.2 & $\begin{array}{l}6 \\
6\end{array}$ & $\begin{array}{l}5 \\
5\end{array}$ & $\begin{array}{l}\text { NE } \\
\text { NW }\end{array}$ & $\begin{array}{l}\text { This study, (Basualto, } \\
\text { 2008; Wicks, 2011) } \\
\text { SERNAGEOMIN }\end{array}$ \\
\hline Chokai & 197312 & $19740301 \mathrm{P}$ & none & 1 & 140 & M3.0? & & Z? & $0-10$ & W & $\begin{array}{l}\text { (Nakamura, 1975; (Ui, et } \\
\text { al. 1977) }\end{array}$ \\
\hline Colima & 19910214 & $10010216 \mathrm{P}$ & 19910301 & 1 & 3 & M3.5 & 14.5 & 2 & 6 & NNW & $\begin{array}{l}\text { This study, UCO (Nunez } \\
\text { Cornu, 1994; }\end{array}$ \\
\hline Colima & 19940704 & $19940721 \mathrm{P}$ & 19940721 & 1 & 2 & M3.4 & 14.5 & 15 & $10-15$ & W? & $\begin{array}{l}\text { This study, UCO } \\
\text { (Jimenez, 1995; Zamora- } \\
\text { Camacho, 2007) }\end{array}$ \\
\hline Colima & 19970620 & $19980706 \mathrm{P}$ & 19981120 & 3 & 4 & M4.0 & 15.1 & 3 & 2 & $\mathbf{W}$ & $\begin{array}{l}\text { This study., UCO (Zamora- } \\
\text { Camacho, 2007) }\end{array}$ \\
\hline Cotopaxi & 20010601 & 20020122 P & none & 1 & 60 & M3.9 & 15.9 & $\begin{array}{l}7 \\
15\end{array}$ & $\begin{array}{l}10 \\
30\end{array}$ & $\begin{array}{l}\mathbf{N} \\
\mathbf{W}\end{array}$ & This study, IGEP \\
\hline El Chichon & 198003 & 19820329 PM & 19820403 & 5 & 132 & M4.2 & 15.7 & & 8 & SE & $\begin{array}{l}\text { This study, (Espindola, 2006; } \\
\text { Jiménez, 1999; Havskov, 1983) }\end{array}$ \\
\hline Fuego, Guate. & 19820217 & $19820223 \mathrm{P}$ & none & 1 & 1 & M3.6 & M3.7 & $7-10$ & 8 & $\mathbf{S}$ & This study, INSIVUMEH \\
\hline Galeras & 19930401 & $19930404 \mathrm{P}$ & 19930607 & 2 & 0.5 & M4.5 & $16.4 ?$ & & 3 & $\mathbf{N}$ & $\begin{array}{l}\text { This study, INGEOMINAS } \\
\text { (Gomez M, 1997; Jimenez, } \\
\text { 2009) }\end{array}$ \\
\hline Galeras & 20051020 & none? & 20060113 & 2 & 1 & M4.7 & 16.5 & 6 & 4 & NW & $\begin{array}{l}\text { This study, INGEOMINAS } \\
\text { (Jimenez, 2009) }\end{array}$ \\
\hline Galeras & 20090509 & $20090509 \mathrm{P}$ & 20090607 & 2 & 0.1 & M4.0 & 15.1 & $\begin{array}{l}10 \\
3 \\
4\end{array}$ & $\begin{array}{l}6 \\
6 \\
5\end{array}$ & $\begin{array}{l}\text { NE } \\
\text { SSE } \\
\text { SW }\end{array}$ & This study, INGEOMINAS \\
\hline G. Pichincha & 19810812 & $\sim 19810820 \mathrm{P}$ & none & 1 & 100 & $M<4$ & $<15.1$ & 4-5 & $5-7$ & SE & This study, IGEP \\
\hline G. Pichincha & 198806 & $\sim 19881007 \mathrm{P}$ & none & 1 & 5 & M3.5 & 14.7 & 5 & $5-7$ & SE & This study, IGEP \\
\hline G. Pichincha & $\sim 19980701$ & $19980807 \mathrm{P}$ & 19990728 & 3 & 5 & M4 & 16 & 14 & 15 & $\mathrm{NE}$ & $\begin{array}{l}\text { This study, IGEP (Villagomez, } \\
\text { 2003) }\end{array}$ \\
\hline Irazu & 199410 & $19941208 \mathrm{P}$ & none & 2 & 17 & M3.4 & 14.2 & 4 & 3 & NNW & This study, OVSICORI \\
\hline Izu-Tobu & 19890630 & 19890711? P & 19890713 & 1 & $\begin{array}{l}\text { Infi- } \\
\text { nite }\end{array}$ & M5.5 & 17.5 & $\begin{array}{l}Z ? \\
4\end{array}$ & $\begin{array}{c}<40 \\
3\end{array}$ & $\begin{array}{c}\text { ESE } \\
N\end{array}$ & $\begin{array}{l}\text { (Okada, 1991; Kasahara, 1991; } \\
\text { Murase, 2010) }\end{array}$ \\
\hline Kanlaon & 20020205 & $20021128 \mathrm{P}$ & none & 1 & 6 & $M<4$ ? & & & & $\mathbf{N}$ & This study, PHIVOLCS \\
\hline Karymsky & 199505 & ???? & 19960102 & 3 & 26 & M6.6 & 19.0 & $10 ?$ & 5 & S? & (Pavlov, 2003) \\
\hline Kasatochi & $<20080720$ & $2008080714 \mathrm{P}$ & 2008080720 & 4 & $109+$ & M5.8 & 18.0 & 10 & 10 & W & AVO (Ruppert, 2011) \\
\hline Kick'em Jenny & 200110 & ??? & 20011204 & $1 ?$ & $10 ?$ & M3 & 13.6 & Z? & $3-5$ & NW & (Lindsay, 2005) \\
\hline Kizimen & 200904 & 20101016 P & 20101213 & 3 & 82 & M5.2 & 17.0 & 5 & 5 & $E$ & (Ji, 2013) \\
\hline Krafla & 19770120 & ??? & 19770427 & 1 & 1 & M4.5 & & Z? & $10-40$ & $0 \mathrm{~N}$ & (Brandsdottir1979) GVP \\
\hline Kuju & ?? & $19951011 \mathrm{P}$ & none & 1 & 257 & M3.0 & & $0-6$ & 5 & NW & (Sudo 1998) \\
\hline Loihi & 19960716 & ??? & 19960522 & $1 ?$ & ??? & M5.1 & 17.5 & Z? & 4.5 & SW & (Caplan-Auerbach, 2001) HVO \\
\hline Mauna Loa & 18680321 & ??? & 18680327 & 2 & 2 & M7.75 & $\sim 20.8$ & "de€ & ep" 20 & $\mathrm{~S}$ & (Wood, 1914) HVO \\
\hline Mauna Loa & 197401 & None & 19750705 & 1 & 25 & M5.5 & 17.5 & $\begin{array}{l}6 \\
6 \\
4\end{array}$ & $\begin{array}{ll}6 & 1 \\
6 \\
4\end{array}$ & $\begin{array}{l}\text { WNW } \\
\text { NNW } \\
\text { SW }\end{array}$ & (Lockwood, 1987) HVO \\
\hline
\end{tabular}




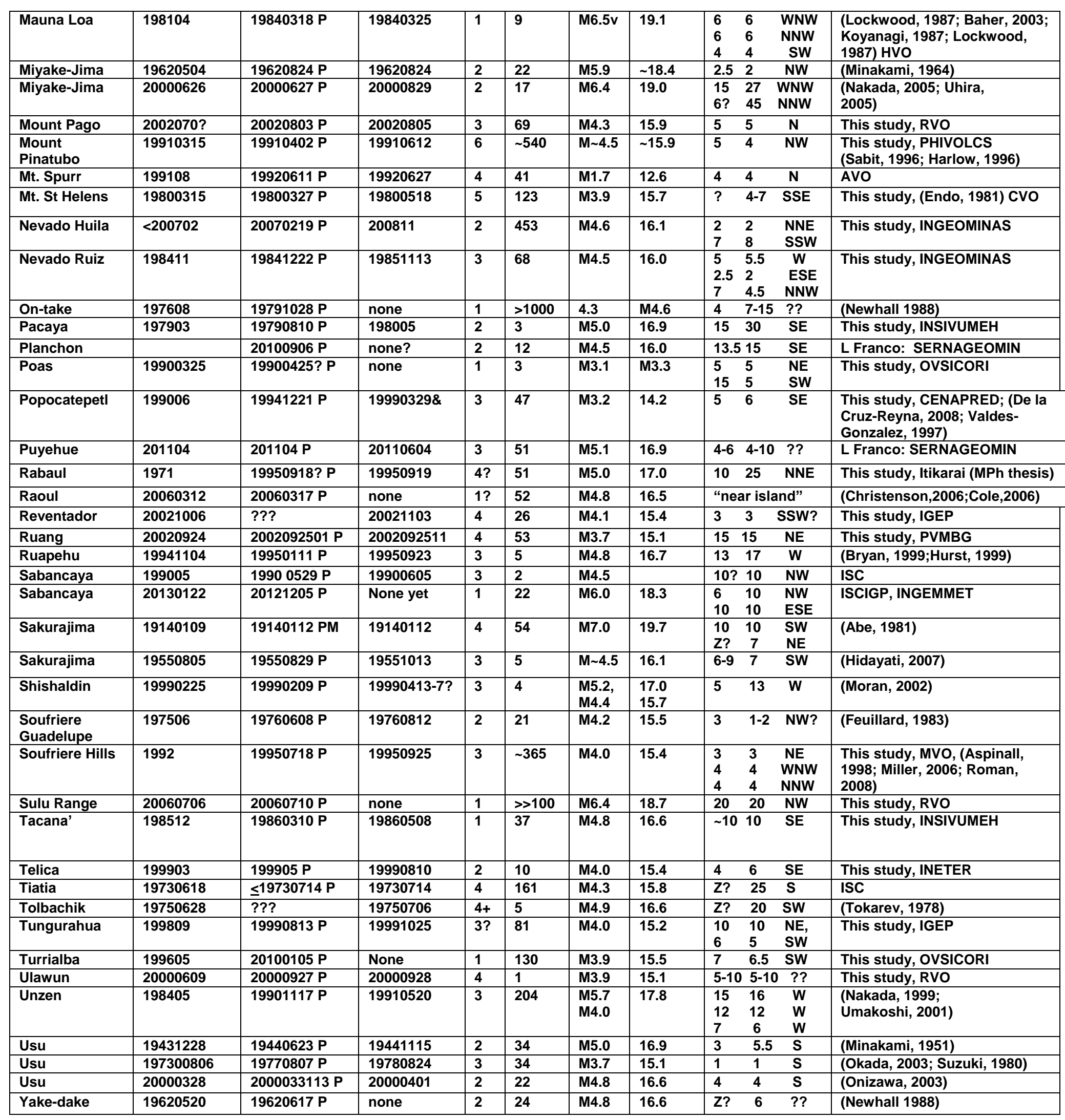


Column 2: Date of $1^{\text {st }}$ known dVT events; $\leq$ indicates $1^{\text {st }}$ know events were either felt events of events recorded by distant stations so small dVT events likely started before this date.

Column 3: Date of initial explosion, whether phreatic (P) or phreatomagmatic (PM), or of a major upswing on fumarolic/phreatic activity in a few cases.

Column 5: VEI explosivity is taken from "Volcanoes of the World" where available, otherwise as estimated from eruption column height.

Column 7: Magnitude of Largest VT, taken from ISC or NEIC catalog where available, otherwise from local coda magnitude. Where two magnitudes are shown, they are the largest for each of two pulses of distal VT seismicity.

Column 8: $\log 10$ of Cumulative Seismic Moment is computed by summing the moments of the 10 largest events where known; otherwise is estimated as twice the moment of the single largest VT.

Column 9: Average Depth and Distance from summit and Azimuth to center of distal VT swarm;

Column 10: References:

"This study" indicates authors personally reviewed seismograms at each observatory, or more recently, over the internet.

For publications, we show only $1^{\text {st }}$ author's last name and date of publication.

Observatories personally visited by these authors to review seismograms:

$\mathrm{AVO}=$ Alaska Volcanoes Observatory, US Geological Survey (Alaska, USA)

$\mathrm{CVO}=$ Cascades Volcanoes Observatory, US Geological Survey (Washington, USA)

HVO = Hawaiian Volcanoes Observatory, US Geological Survey (Hawaii, USA)

IGEP = Instituto Geofisico Escuela Politecnica (Quito, Ecuador)

IGP= Instituto Geologico de Perú (Arequipa, Perú)

INGEMMET = Instituto Geologico Minero y Metalúrgico (Arequipa, Perú)

INETER = Instituto Nicaragüense de EstudiosTerritoriales (Managua, Nicaragua),

INGEOMINAS (now SGC = Servicio Geologico Colombiano (Manizales, Popayan and

Pasto, Colombia)

INSIVUMEH = Instituto Sismologico, Vulcanologico, Meteorologico, y Hidrologioco

(Guatemala City, Guatemala),

KVERT = Kamchatka Volcanic Eruption Response Team: Institute of Volcanology and Seismology FEB (Russia RAS)

MVO = Montserrat Volcano Observatory (Montserrat, British West Indies)

OVSICORI = ObservatorioVulcanologico y Sismologico (Heredia, Costa Rica)

PHIVOLCS = Philippine Institute of Volcanology and seismology (Quezon City, Philippines)

PVMBG = Pusat Vulkanologi \& Mitigasi Bencana Geologi (Bandung, Indonesia)

RVO = Rabaul Volcano Observatory (Rabaul, Papua New Guinea)

SERNAGEOMIN = Servicio Nacional de Geología y Minería (Temuco, Chile)

SNET (now MARN = Ministerio de Medio Ambiente y Recursos Naturales (San Salvador, el Salvador)

$\mathrm{UCO}=$ University of Colima (Colima, Mexico) 
TABLE 2 Eruptions with inferred precursory distal VT earthquake swarms

\begin{tabular}{|c|c|c|c|c|}
\hline Volcano & $\begin{array}{l}\text { Start Date of } \\
\text { Magmatic } \\
\text { Eruption }\end{array}$ & VEI & $\begin{array}{l}\text { Maximum } \\
\text { Magnitude }\end{array}$ & References \# \\
\hline Alaid & 19810427 & 4 & M4.6? & GVP, ISC \\
\hline Arenal & 196806 & 3 & $\leq 4.5$ & (Barquero, 1992) \\
\hline Askja & 18750218 & 5 & $\overline{\mathrm{M} 6-7}$ & (Thorarinsson, 1962) \\
\hline Augustine & 19860228 & $4 ?$ & M4.3 & AVO (Power, 2010) \\
\hline Beerenberg & 19700918 & 3 & M5.7 & (Zobin, 2001) \\
\hline Beerenberg & 19850106 & 2 & M5.0 & (Zobin, 2001) \\
\hline Bezymianny & $\sim 19551116$ & 5 & $M \sim 5.5$ & (Gorshkov, 1959) \\
\hline Cerro Hudson & 19910814 & $5+$ & M5.0 & (Naranjo S., 1991) SERNAGEOMIN \\
\hline Colo Una-Una & 19830720 & 4 & M5.8 & (Conte, 1999 ;Katili, 1990) \\
\hline Colo Una-Una & 18980502 & $3+$ & M5? & (Katili, 1990) \\
\hline Curacoa & 19730712 & 3 & M5.9 & (Okada, 1983)(Latter, 1976) \\
\hline Deception Is & 19671204 & 3 & $\mathrm{M} \sim 5$ & \begin{tabular}{|l|} 
(Lorca, 1976) \\
\end{tabular} \\
\hline Fernandina & 19680611 & 4 & M5.4? & (Filson, 1973;Kaufman, 1980) \\
\hline Fernandina & 20050513 & 2 & M5.0 & GVP, ISC \\
\hline Fuji & 17071216 & 5 & $\sim \mathrm{M} 4$ ? & (Tsuya, 1955;Omori, 1911) \\
\hline Grimsvotn & 19960930 & 3 & M5.6 & \begin{tabular}{|l} 
(Zobin, 2001) \\
\end{tabular} \\
\hline Hibok-Hibok & 19511204 & 3 & ?? & \begin{tabular}{|l} 
(Macdonald, 1956) \\
\end{tabular} \\
\hline Huaynaputina & 16000220 & 6 & M7 & (Adams, 2001;De Silva, 1998) \\
\hline Kliuchevskoi & 19511119 & 2 & ??? & (Gorshkov, 1960) \\
\hline Kelut & 19900210 & 4 & $\mathrm{M}<4$ & GVP \\
\hline Kelut & 20071004 & 2 & $\leq \mathrm{M} 3.7$ & ISC \\
\hline Kliuchevskoi & 1966 & 3 & $\overline{\mathrm{M}} 4 ?$ & (Tokarev, 1966) \\
\hline Lamington & 19510121 & 4 & ?? & (Taylor, 1991) \\
\hline Loquimay & 19881225 & 3 & M5.2 & \begin{tabular}{|l|} 
(Zobin, 2001) \\
\end{tabular} \\
\hline Momotombo & 1905 & 2 & M5.0 & \begin{tabular}{|l} 
(Leeds, 1974). \\
.
\end{tabular} \\
\hline Novarupta & 19120606 & 6 & $<\mathrm{M} 4.5, \mathrm{M} 7$ & (Abe, 1992) \\
\hline Pagan & 19810515 & 4 & $\sim \mathrm{M} 4.5$ & (Banks, 1984) \\
\hline Santa Maria & 19021024 & 6 & M5+? & (Williams, 1983) Rose \\
\hline Sheveluch & 19641112 & $4+$ & M5.5 & (Zobin, 1970, 2001) \\
\hline Souf. St. Vincent & 18120430 & 4 & $\mathrm{M} \sim 4$ ? & (Anderson, 1903) \\
\hline Souf. St. Vincent & 19020505 & 4 & $\mathrm{M} \sim 4$ & (Anderson, 1903) \\
\hline Tolbachik & 20121126 & 3 & M3.5? & KVERT \\
\hline Ukinrek Maars & 19770403 & 3 & M4.5 & (Kienle, 1980) AVO \\
\hline Ulawun & 19801006 & 3 & strong & GVP \\
\hline Unzen & 17920210 & 2 & M5-5.5 & \begin{tabular}{|l|} 
(Omori, 1928). \\
\end{tabular} \\
\hline Usu & 16630816 & 5 & $M>4$ & (Omori, 1911) \\
\hline Usu & 18220312 & 4 & $M>4$ & \begin{tabular}{|c|c|} 
(Omori, 1911) \\
\end{tabular} \\
\hline Usu & 19100725 & 2 & M5.5 & \begin{tabular}{|l} 
(Omori, 1911) \\
\end{tabular} \\
\hline
\end{tabular}

\# References give last name of $1^{\text {st }}$ author only, and date of publication; ALL CAPS indicate institutions detailed in Table 1 
Table 3 Cumulative Magnitude and Seismic Moment versus 1) intruded magma volume where known, 2) extruded magma volume for basaltic eruptions, and 3) and injected $\mathrm{H} 2 \mathrm{O}$ volume at deep wells.

\begin{tabular}{|c|c|c|c|c|c|c|c|c|}
\hline Date & Location & $\begin{array}{l}\text { Maxi- } \\
\text { mum } \\
\text { Magni- } \\
\text { tude }\end{array}$ & $\begin{array}{l}\text { Cumu- } \\
\text { lativeMagni- } \\
\text { tude }\end{array}$ & $\begin{array}{l}\text { Cumu- } \\
\text { lative } \\
\text { Moment } \\
\text { (N-m) } \\
\end{array}$ & $\begin{array}{l}\text { Intruded } \\
\text { Volume } \\
\text { millions } \\
\text { of } \mathrm{m} 3 \\
\end{array}$ & $\begin{array}{l}\text { Extruded } \\
\text { Volume* } \\
\text { millions } \\
\text { of } \mathrm{m} 3\end{array}$ & $\begin{array}{l}\text { Log10 } \\
\text { of } \\
\text { Volume } \\
\text { in m3 }\end{array}$ & References\# \\
\hline & VOLCANOES & & & & & & & \\
\hline 1868 & Mauna Loa & 7.8 & 7.80 & $6.31 \mathrm{E}+20$ & & 3200 & 9.50 & $\begin{array}{l}\text { Tilling (1987), Klein } \\
\text { (2008) }\end{array}$ \\
\hline 1977 & Ukinrek Maars & 4.5 & 4.70 & $1.41 \mathrm{E}+16$ & & 2.5 & 6.40 & Kienle (1980) \\
\hline 1999 & Shishaldin & 5.1 & 5.20 & $7.94 \mathrm{E}+16$ & & 14 & 7.10 & Moran (2012) \\
\hline 1996 & Akutan & 5.1 & 6.00 & $2.70 \mathrm{E}+18$ & 34 & & 7.50 & Lu (2005) \\
\hline 1996-98 & Mt. Peulik & 5.2 & 5.90 & $7.17 \mathrm{E}+17$ & 50 & & 7.70 & Lu (2005) \\
\hline $1978-80^{*}$ & Long Valley & 6.2 & 6.40 & $5.01 \mathrm{E}+18$ & 70 & & 7.90 & Langbein (1995) \\
\hline 1981-99 & Long Valley & 6.4 & 6.70 & $7.08 \mathrm{E}+18$ & 180 & & 8.40 & Langbein (1995) \\
\hline 1966 & Matsushiro & 5.3 & 6.30 & $3.55 \mathrm{E}+18$ & 125 & & 8.00 & Ohtake (1976) \\
\hline 1989 & Poas & 3.2 & 3.40 & $1.58 \mathrm{E}+14$ & 0.04 & & 4.70 & Rymer (2000) \\
\hline 1984 & Mauna Loa & 6.7 & 6.75 & $1.68 \mathrm{E}+19$ & & 220 & 8.35 & Lockwood (1987) \\
\hline 1975 & Mauna Loa & 5.3 & 5.70 & $4.56 \mathrm{E}+17$ & & 30 & 7.48 & Lockwood (1987) \\
\hline 2010 & Kizimen & 5.0 & 5.40 & $1.58 \mathrm{E}+17$ & 25 & & 7.40 & Ji (2013) \\
\hline 2000 & Usu & 5.0 & 5.30 & $1.00 \mathrm{E}+17$ & 40 & & 7.60 & Jousset (2003) \\
\hline 1984 & Tori Shima & 5.5 & 5.60 & $4.00 \mathrm{E}+17$ & 40 & & 7.60 & Kanamori (1993) \\
\hline & DEEP WELLS & & & & $\begin{array}{c}\text { Injected } \\
\text { volume } \\
10 \mathrm{e} 6 \mathrm{~m} 3\end{array}$ & & & \\
\hline 2000 & KTB well & 0.7 & 1.50 & $2.24 \mathrm{E}+11$ & 0.0002 & & 2.30 & McGarr (2014) \\
\hline 1970 & Matsushiro & 2.6 & 2.80 & $2.00 \mathrm{E}+13$ & 0.0029 & & 3.45 & Ohtake (1974) \\
\hline $\begin{array}{l}1991- \\
2005\end{array}$ & Paradox well & 4.3 & 4.50 & $7.10 \mathrm{E}+15$ & 0.4500 & & 5.67 & McGarr (2014) \\
\hline 1967-68 & Denver, CO & 4.9 & 5.1 & $5.10 \mathrm{E}+16$ & 0.6250 & & 5.93 & McGarr (2014) \\
\hline $2010-11$ & Bowland, UK & 2.3 & 2.50 & $3.20 \mathrm{E}+12$ & 0.0042 & & 3.61 & McGarr (2014) \\
\hline 2011 & Garvin, OK & 3.0 & 3.3 & $1.12 \mathrm{E}+14$ & 0.0089 & & 3.95 & McGarr (2014) \\
\hline $2000-06$ & Soults, France & 2.9 & 3.20 & $7.94 \mathrm{E}+13$ & 0.0389 & & 4.60 & McGarr (2014) \\
\hline 2006 & $\begin{array}{l}\text { Basel, } \\
\text { Switzerland }\end{array}$ & 3.4 & 3.70 & 4.47E+14 & 0.0115 & & 4.10 & McGarr (2014) \\
\hline 1987 & Ashtabula, $\mathrm{OH}$ & 3.6 & 3.90 & $8.91 \mathrm{E}+14$ & 0.0617 & & 4.80 & McGarr (2014) \\
\hline 2001 & Ashtabula, $\mathrm{OH}$ & 3.9 & 4.20 & $2.51 \mathrm{E}+15$ & 0.3400 & & 5.55 & McGarr (2014) \\
\hline 2001 & Raton Bas, CO & 4.4 & 4.70 & $4.50 \mathrm{E}+15$ & 0.3650 & & 5.60 & McGarr (2014) \\
\hline 2005 & Raton Bas, CO & 5.1 & 5.30 & $1.12 \mathrm{E}+17$ & 2.9200 & & 6.50 & McGarr (2014) \\
\hline 2011 & Raton Bas, CO & 5.3 & 5.60 & $3.16 \mathrm{E}+17$ & 4.9500 & & 6.70 & McGarr (2014) \\
\hline $2010-11$ & Guy, AR & 4.7 & 5.0 & $4.00 \mathrm{E}+16$ & 0.6290 & & 5.70 & McGarr (2014) \\
\hline $1985-86$ & Painesville, $\mathrm{OH}$ & 4.8 & 5.1 & $5.62 \mathrm{E}+16$ & 1.1900 & & 6.10 & McGarr (2014) \\
\hline $2010-11$ & Prague, OK & 5.7 & 6.0 & $1.26 \mathrm{E}+18$ & 12.0000 & & 7.10 & McGarr (2014) \\
\hline
\end{tabular}

\# References give last name of $1^{\text {st }}$ author only, and date of publication

* Note: for Mauna Loa and other basaltic volcanoes such as Ukinrek Maars and

Shishaldin, all of the intruded volume

is generally considered to eventually erupt. 
TABLE 4 Intrusions with known precursory distal VT earthquake swarms

\begin{tabular}{|c|c|c|c|c|c|c|}
\hline Volcano & $\begin{array}{l}\text { Date of VT } \\
\text { swarm }\end{array}$ & $\begin{array}{c}\text { Depth (km), } \\
\text { Distance, } \\
\text { Azimuth }\end{array}$ & \begin{tabular}{|l} 
Maxi- \\
mum \\
Magni- \\
tude
\end{tabular} & $\begin{array}{l}\text { Cumu- } \\
\text { lative } \\
\text { Magni- } \\
\text { tude }\end{array}$ & References \# & $\begin{array}{l}\text { Evidence of magma } \\
\text { intrusion }\end{array}$ \\
\hline Akutan & 199603 & $5, \quad 6$ ESE & 5.1 & 6 & AVO, (Lu, 2000) & InSAR inflation \\
\hline Apoyeque & 20120906 & $5,6 \mathrm{SE}$ & 3.8 & 4.3 & This study, INETER & $\begin{array}{l}\text { Episodic seismic } \\
\text { swarms }\end{array}$ \\
\hline Baru & 1985,2006 & 6? $6 \mathrm{E}$ & 4.2 & 4.4 & $\begin{array}{l}\text { This study, Univ. } \\
\text { Panama }\end{array}$ & $\begin{array}{l}\text { Episodic seismic } \\
\text { swarms }\end{array}$ \\
\hline Chanbaishan & $2002-03$ & $\begin{array}{lll}3.5 & 3 & \text { SW }\end{array}$ & 2.8 & 2.9 & (Wu 2007) & Inflation, geochemical \\
\hline Cosiguina & 200209 & $5,4-6 \mathrm{NW}$ & 3.9 & 4.3 & This study, INETER & $\begin{array}{l}\text { Episodic seismic } \\
\text { swarms }\end{array}$ \\
\hline Deception Is & 1998-9 & $2, \quad 3 \quad \mathrm{NNE}$ & 3.4 & 4.6 & (Ibanez 2003) & SO2 \\
\hline Dutton & $198807-8$ & 1-10,1-10SE & 3.8 & 4.0 & AVO & $\begin{array}{l}\text { Episodic seismic } \\
\text { swarms }\end{array}$ \\
\hline Great Sitkin & 20020518 & $? \quad 6$ SSE & 4.6 & 4.7 & AVO & Tremor \\
\hline Hakone & 199008 & $5 E$ & 5.1 & $5.2 ?$ & GVP & $\begin{array}{l}\text { Episodic seismic } \\
\text { swarms }\end{array}$ \\
\hline Iliamna & 199609-12 & $5, \quad 5 \mathrm{~S}$ & 3.2 & $3.4 ?$ & AVO (Roman 2004) & InSAR inflation \\
\hline Koryaksky & 200803-04 & $5, \quad 5$ SW & 3.3 & 3.5 & GVP & $\mathrm{SO} 2$ \\
\hline Long Valley & $1978-80$ & $5, \quad 5 \mathrm{~S}$ & 6.2 & 6.5 & CalVO (Hill 2006) & Inflation, CO2 \\
\hline Puerto Aysen & $200701-04$ & $? ?$ & 6.2 & 6.3 & $\begin{array}{l}\text { SERNAGEOMIN, } \\
\text { (Legrand 2011) }\end{array}$ & InSAR inflation \\
\hline Machin & 200081108 & $6, \quad 6 \mathrm{SE}$ & 4.6 & 4.7 & $\begin{array}{l}\text { This study, } \\
\text { INGEOMINAS }\end{array}$ & $\begin{array}{l}\text { Inflation, springs appear } \\
\text { and/or turn white }\end{array}$ \\
\hline Mammoth Mtn & 198905 & $8,6 \mathrm{~S}$ & 3.4 & 3.7 & $\begin{array}{l}\text { CalVO, (Hill 1990; } \\
\text { Hill 2005) }\end{array}$ & Inflation, CO2, Trees die \\
\hline $\begin{array}{l}\text { Mt Minakame, } \\
\text { Matsushiro, }\end{array}$ & $1966-67$ & $2 \quad 2.5 \mathrm{SE}$ & 5.3 & 6.3 & $\begin{array}{l}\text { (Ohtake 1976; } \\
\text { Stuart 1975) }\end{array}$ & $\mathrm{H} 2 \mathrm{O}$, deformation \\
\hline Mehetia & 19800306 & $13 \quad 10 \mathrm{SE}$ & 4.3 & 4.6 & GVP & High b-value \\
\hline Momotombo & 20000609 & $5, \quad 5 \mathrm{SE}, \mathrm{E}$ & 4.1 & 4.3 & GVP, INETER & High temperatures \\
\hline Mount Peulik & 1996-98 & $15 ?, 30 \mathrm{NW}$ & 5.2 & 5.4 & AVO, Lu 2002) & InSAR inflation \\
\hline Taal & $1991-92$ & $2-5,3 \mathrm{E}$ & 3 & $3.2 ?$ & (Newhall 1988) & $\begin{array}{l}\text { Phreatic explosions, } \\
\text { Cracks }\end{array}$ \\
\hline Yellowstone & 198506 & $10,20 \mathrm{NW}$ & 4.9 & $5.1 ?$ & (Waite 2002) & Inflation/deflation \\
\hline
\end{tabular}

\# References give last name of $1^{\text {st }}$ author only, and date of publication; ALL CAPS indicate institutions detailed in Table 1 


\section{Figures}

Figure 1: Seismicity prior to the 1991 VEI 6 eruption of Mount Pinatubo, the largest eruption of the last 100 years. A: Instrumentally located epicenters from May 15 to Cataclysmic eruption onset June 15, 1991. Blue circles are distal VT events; red circles are proximal events, mainly hybrid events; black circles are relocated events within those two areas (Jones et al., 2001); Black squares are towns where early felt events were reported. B: Seismicity along NW-SE transect versus time. C: Cross-section along NW-SE transect. Blue shading between the two gray lines indicates area where early felt events were reported 4-8 km west and northwest of the summit. D: Log10 of the daily cumulative Seismic Moment Cumulative and the daily cumulative magnitude versus time. Blue line is for the distal VT moment, dashed where inferred from felt seismicity reports; fuchsia line is for low frequency seismicity and tremor; red line indicates hybrid-type low frequency seismicity. Blue arrow indicates initial phreatic explosion. Smaller orange-red arrow indicates the start and growth of dome extrusion; large orange-red arrow indicates cataclysmic eruption.

Figure 2: Seismicity prior to and during onset of the 1995-2003 eruption of Soufriere Hills volcano, Montserrat, British West Indies. A: epicenters for 1 Oct 1994 to 1 Jan 1996. Pale blue circles are distal VT's located by the sparse regional seismograph network of the Seismic Research Unit; the rest are epicenters determined using the on-island seismic network. Dark blue circles show the best $10 \%$ of preliminary distal VT locations; green circles show distal event relocations for many of the same events (Roman et al., 2007); red circles show proximal preliminary epicenter locations while orange circles show highprecision relocations for most of those same events (Rowe et al., 2004). The 4 circle sizes, smallest to largest, indicate $0<M<1,1 \leq M<2,2 \leq M<3$, and $3 \leq M<4$ respectively. B: Seismicity versus time along W-E transect. C: Cross-section seismicity along W-E transect (East at top). D: Cumulative magnitude and Log10 of cumulative seismic moment versus time. Blue dots indicate distal VT's, red triangles indicate proximal events; red line is 3-day running average of the proximal events. Blue arrows indicate times of phreatic eruptions; orange-red arrows indicate onsets of dome extrusions.

Figure 3: Seismicity prior to and during the 1991-1995 eruption of Mount Unzen, Japan. Blue circles are VT events from the ISC catalog prior to Dec 1984, and from Dec 1984 onward from Dr. Kodo Umakoshi and Dr. Hiroshi Shimizu (personal communication; red circles are proximal events, mainly hybrid events, from Dr. Kodo Umakoshi and Dr. Hiroshi Shimizu (personal communication). Circles indicate magnitude, from smallest to largest: $M<1,1 \leq M<2$, $2 \leq M<3,3 \leq M<4,4 \leq M<5$ and $5 \leq M \leq 5.7 ; B$ : Seismicity along $S W-N E$ transect versus time. $C$ : Cross-section along SW-NE transect; symbols same as in B. D: Daily cumulative magnitude and Log10 of the daily cumulative seismic moment versus time. Large blue circle indicates largest event, M 5.7; red circles indicate proximal events; red line is weekly running average of proximal seismicity. 1st blue arrow indicates $1^{\text {st }}$ phreatic explosion, $2^{\text {nd }}$ blue arrow 
indicates time of resumed phreatic eruptions; orange-red bar indicates duration of dome extrusions.

Figure 4: Seismicity prior to and during the 1986 phreatic eruption of Tacana', on the Guatemala-Mexico border. A: Blue circles indicate distal VT seismicity; red circles indicate proximal seismicity. B: Daily cumulative magnitude and Log10 of the daily cumulative seismic moment versus time. Blue line indicates distal VT seismicity; red line indicates proximal seismicity; dashed blue arrow indicates possible small phreatic eruption; solid lined blue arrow indicates phreatic explosion. Green bar indicates period of small amplitude tremor.

Figure 5: Kasatochi seismograms for short-period seismic station GSMY for 48 hours starting at 00:00 Alaskan Daylight time August 6, 2008. Each line is 30 minutes long. Inset shows how the total seismic energy released per unit time gradually ramped up, with the magnitude of the largest event increasing at least 10 times up to the largest event which occurred late in the sequence. Although this ramp up was relatively rapid compared to most eruptions in Table 1, ramp up is typical of DVT swarms and is the most obvious difference from tectonic seismicity in which the largest event occurs at or very near the beginning of a sequence.

Figure 6: Average depth and distance of each distal VT swarm from summit or eruption site (top left corner) for each eventual eruption. Dots indicate the approximate center of each distal VT swarm. Note that swarms appear to sweep a curve, generally occurring at greater depths farther from the summit. Note that the DVT swarms seem to occur within the lower portion of the brittle crust.

Figure 7: Daily cumulative magnitude and Log10 of the cumulative seismic moment versus Log10 of intruded magma volume for eruptions, where the volume can be estimated from deformation or other non-seismic data, and Log10 of injected $\mathrm{H} 2 \mathrm{O}$ volume for deep wells.

Figure 8: Seismicity associated with the large 2006 intrusion and phreatic eruptions at the Sulu Range, New Britain Island, Papua New Guinea. A: Beach balls show the Harvard Moment Tensor solutions for the epicenters of $M \geq 5.0$ distal VT events. Diagonal yellow line indicates inferred fault on which these $M \geq 5.0$ events occurred. Colors indicate the ALOS LBand Interferogram spanning June 6 to July 22, 2006 showing about $1 \mathrm{~m}$ of peak to peak deformation near the Sulu Range (from Wicks et al., 2011). Black circles show epicenters of mainly the onshore events located by a temporary seismograph network installed by Geoscience Australia in late July 2006. B: Log10 of the seismic moment. Blue line indicates VT seismicity, dashed where inferred. Blue arrow indicates time of phreatic explosions 


\section{References:}

Abe, K., Seismometrical re-evaluation of the Sakurajima earthquake of January 12, 1914. Geophys. Bull., Hokkaido Univ, 1981. 39: 57-62.

Abe, K. (1992). Seismicity of the caldera-making eruption of Mount Katmai, Alaska in 1912. Bulletin of the Seismological Society of America 82(1): 175-191.

Adams, N. K., S. de Silva, S. Self, G. Salas, S. Schubring, J. Permenter, and K. Arbesman, (2001). "The physical volcanology of the 1600 eruption of Huaynaputina, southern Peru." Bulletin of Volcanology 62(8): 493-518.

Aspinall, W.P., A.D. Miller, L.L. Lynch, J.L. Latchman, R.C. Stewart, R.A. White, and J.A. Power, 1998, Soufriere Hills eruption, Montserrat, 1995-1997; volcanic earthquake locations and fault plane solutions; [Monograph] The Soufriere Hills eruption, Montserrat, British West Indies; introduction to special section; Part 1: Geophysical Research Letters 25(18) 3397-3400.

Baher, S., C. Thurber, K. Roberts, and C. Rowe, Relocation of seismicity preceding the 1984 eruption of Mauna Loa Volcano, Hawaii: Delineation of a possible failed rift.J. Volcanol. Geotherm. Res., 2003. 128(4): 327-339.

Banks, N. G., Koyanagi, R. Y., Sinton, J. M., and Honma, K. T. (1984). The eruption of Mount Pagan Volcano, Mariana Islands, 15 May 1981. Journal of Volcanology and Geothermal Research, 22(3), 225-269.

Baptie, B., R. Luckett, and J. Neuberg. Observations of low-frequency earthquakes and volcanic tremor at Soufriere Hills Volcano, Montserrat. Geological Society, London, Memoirs 21.1 (2002): 611-620.

Basualto, D., P. Pena, C. Delgado, C. Gallegos, H. Moreno, and J.O. Munoz, Seismic activity related to the evolution of the explosive eruption of Chaiten Volcano in the Southern Andes volcanic zone. Eos, Transactions, Am. Geophys. Union, 2008. 89(53, Suppl.): Abstract V43D-2178.

Brandsdottir, B. and P. Einarsson, Seismic activity associated with the September 1977 deflation of the Krafla central volcano in northeastern Iceland.J. Volcanol. Geotherm. Res., 1979. 6(3): 197-212.

Bryan, C.J. and S. Sherburn, Seismicity associated with the 1995-1996 eruptions of Ruapehu volcano, New Zealand: narrative and insights into physical processes.J. Volcanol. Geotherm. Res., 1999. 90(1-2): 1-18.

Caplan-Auerbach, J. and F.K. Duennebier, Seismicity and velocity structure of Loihi Seamount from the 1996 earthquake swarm. Bulletin of the Seismological Society of America, 2001. 91(2): 178-190.

Cardona, C., R. White, W. McCausland, N. Trujillo, A. Narvaez, R. Bolanos, and O. Manzo. Sismicidad tipo" drumbeat" asociada a la erupción y emplazamiento de un domo en el volcán Nevado del Huila, noviembre de 2008. Memorias XII Congreso Colombiano de Geología (2009).

Chicangana, G. ,The Romeral Fault System: A shear deformed extinct subduction zone between Oceanic and Continental lithospheres in Northwestern South America. Earth Sciences Research Journal (2005) 9(1), 51-66.

Chouet, Bernard. "Volcano Seismology." Pure and Applied Geophysics 160, no. 3-4 (2003): 739-788.

Christenson, B.W., A.G. Reyes, and C. Werner, The 2006 eruption of Raoul Volcano (Kermadecs); a magmatic-hydrothermal event from a hydrothermally-sealed volcanic conduit system. Geological Society of New Zealand Misc. Publication, 2006. 122A: 8-9.

Cole, J.W., H.A. Cowan, and T.H. Webb, The 2006 Raoul Island eruption; a review of GNS Science's actions. GNS Science Report, 2006: 35-35.

Conte, A.M., C. Freda, M. Gaeta, and D.M Palladino, Mechanism for the 1983 eruption of Colo Volcano, Una-Una Island, Indonesia. Acta Vulcanologica, 1999. 11(2): 245-254.

De la Cruz-Reyna, S., I. Yokoyama, A, Martínez-Bringas, and E. Ramos, E. Precursory seismicity of the 1994 eruption of Popocatepet/ Volcano, Central Mexico. Bull. Volcanol., 2008. 70(6): 753-767. 
De Silva, S. L. and G. A. Zielinski (1998). Global influence of the AD 1600 eruption of Huaynaputina, Peru. Nature_393(6684): 455-458.

Dreger, D. S., Tkalčić, H., and Johnston, M. (2000). Dilational processes accompanying earthquakes in the Long Valley Caldera. Science, 288(5463), 122-125.

Druitt, T. H. and B. P. Kokelaar (eds.), The eruption of Soufrière Hills volcano, Montserrat, from 1995 to 1999, Geological Society of London (2002).

Ekström, G., and Dziewonski, A. M. (1985). Centroid-moment tensor solutions for 35 earthquakes in western North America (1977-1983). Bulletin of the Seismological Society of America, 75(1), 23-39.

Endo, E.T., S.D. Malone, L.L. Noson, and C.S. Weaver, Locations, magnitudes, and statistics of the March 20-May 18 earthquake sequence. U. S. Geological Survey Professional Paper, 1981: 93-107.

Espindola, J.M., A. Zamora-Camacho, and Z. Jimenez, Some aspects of the seismicity associated with the 1982 eruption of El Chichon Volcano, Chiapas, Mexico, J. Volcanol. Geotherm. Res., 2006. 157(4): 367-374.

Feuillard, M., CJ Allegre, G Brandeis, R Gaulon, J.L. Lw Mouel, J.C. Mercier, J.P. Pozzi, and M.P. Semet, The 1975-1977 crisis of La Soufriere de Guadeloupe (F.W.I.); a still-born magmatic eruption.J. Volcanol. Geotherm. Res., 1983. 16(3-4): 317-334.

Fisher, M.A., N.A. Ruppert, R.A. White, F.H. Wilson, D. Comer, R.W. Slater, and F.L. Wong, Distal volcano-tectonic seismicity near Augustine Volcano. U. S. Geological Survey Professional Paper, 2010: 119-128.

Filson, J., T. Simkin, and L. Leu, (1973). Seismicity of a caldera collapse: Galapagos Islands 1968. Journal of Geophysical Research 78(35): 8591-8622.

Foulger, G. R., B. Julian, D.Hill, M. Pitt, P. Malin, and E. Shalev, (2004). Non-double-couple microearthquakes at Long Valley caldera, California, provide evidence for hydraulic fracturing. J. Volcanol. Geotherm. Res., 132(1), 45-71.Fournier, R. and A. Pitt (1985). The Yellowstone magmatic-hydrothermal system, USA.

Gardner, C. A., and R. A. White. Seismicity, gas emission and deformation from 18 July to 25 September 1995 during the initial phreatic phase of the eruption of Soufrière Hills Volcano, Montserrat. Geological Society, London, Memoirs 21.1 (2002): 567-581.

Gomez M, D.M., R.A. Torres C, and Anonymous, $A$ volcano-tectonic (?) seismic source around Galeras Volcano, Colombia. 1997: Mexico (MEX). 128.

Gorshkov, G.S., Gigantic eruption of the volcano Bezymianny. Bull. Volcanol., 1959. 20: 77-109.

Gorshkov, G.S., Some results of seismometric investigations at the Kamchatka Volcanological Station. Bull. Volcanol., 1960. 23: 121-128.

Hanks, T. C., and Kanamori, H. (1978). Moment Magnitude Scale. In Transactions- American Geophysical Union (Vol. 59, No. 12, pp. 1128-1128). 2000 Florida Ave NW, Washington, DC 20009: Amer Geophysical Union.

Harlow, D.H., J.A. Power, E.P. Laguerta, G. Ambubuyog, R.A. White, and R.P. Hoblitt, 1996, Precursory seismicity and forecasting of the June 15, 1991, eruption of Mount Pinatubo. IN: Fire and Mud: Eruptions and Lahars of Mount Pinatubo, Phillippines. University of Washington Press, Seattle (1996): pp. 285-306.

Havskov, J., S. De La Cruz-Reyna, S.K. Singh, F. Medina, and C. Gitierrez, Seismic activity related to the March-April, 1982 eruptions of El Chichon Volcano, Chiapas, Mexico. Geophys. Res. Lett. , 1983. 10(4): p. 293-296.

Hermosilla Pineda, G., Actividad sismica precursora a la erupcion del volcan Hudson, el 26 de Octubre de 2011. 2012, Servicio Nacional de Geologia y Mineria (Temuco, Chile) Temuco, Chile. p. 39. 
Hidayati, S., K. Ishihara, and M. Iguchi, Volcano-tectonic earthquakes during the stage of magma accumulation at the Aira caldera, southern Kyushu, Japan. Bull. Volcanol. Soc. Japan, 2007. 52: 289-309.

Hill, David P. A model for earthquake swarms. Journal of Geophysical Research 82.8 (1977): 13471352.

Hill, D., W. Ellsworth, M. Johnston, J. Langbein, D. Oppenheimer, M. Pitt, P. Reasenberg, M. Sorey, and S. McNutt, The 1989 earthquake swarm beneath Mammoth Mountain, California: An initial look at the 4 May through 30 September activity. Bulletin of the Seismological Society of America (1990) 80(2): 325-339.

Hill, D. P. (2006). Unrest in Long Valley Caldera, California, 1978-2004. Geological Society, London, Special Publications 269(1): 1-24.

Hill, D. P. and S. Prejean (2005). Magmatic unrest beneath mammoth mountain, California. Journal of Volcanology and Geothermal Research 146(4): 257-283. Hurst, A.W. and P.J. McGinty, Earthquake swarms to the west of Mt Ruapehu preceding its 1995 eruption. J. Volcanol. Geotherm. Res., 1999. 90(1-2): 19-28.

Ibáñez, J., E.D. Pezzo, J. Almendros, M. La Rocca, G. Alguacil, R., Ortiz, and A. García, (2003). The 19981999 seismic series at Deception Island volcano, Antarctica. Journal of Volcanology and Geothermal Research 128(1): 65-88.

Ito, K. (1993). Cutoff depth of seismicity and large earthquakes near active volcanoes in Japan. Tectonophysics, 217(1), 11-21.

Ji, L., Z. Lu, D. Dzurisin, and S. Senyukov, Pre-eruption deformation caused by dike intrusion beneath Kizimen volcano, Kamchatka, Russia, observed by InSAR. J. Volcanol. Geotherm. Res., 2013. 256: 87-95.

Jimenez, M.J., M. Garcia-Fernandez, and J. Romero, 1989 -1995 Earthquake sequences in the Galeras volcano region, SW Colombia, and possible volcano -earthquake interactions. Tectonophysics, 2009. 463(1-4): 47-59.

Jimenez, Z., G. Reyes, and J.M. Espindola, The July 1994 episode of seismic activity at Colima Volcano, Mexico. J. Volcanol. Geotherm. Res., 1995. 64(3-4): 321-326.

Jiménez, Z., V.H. Espíndola, and J.M. Espíndola, Evolution of the seismic activity from the 1982 eruption of El Chichon Volcano, Chiapas, Mexico.Bull. Volcanol., 1999. 61(6): 411-422.Jones, J.P., C.H. Thurber, and W.J. Lutter, High-precision location of pre-eruption seismicity at Mount Pinatubo, Philippines, 30 May-3 June, 1991. Physics of Earth and Planetary Interiors, 2001. 123:221-232.

Jones, J. P., C. thurber, and W. Lutter, (2001). High-precision location of pre-eruption seismicity at Mount Pinatubo, Philippines, 30 May-3 June, 1991. Physics of the Earth and Planetary Interiors 123(2): 221-232.

Jousset, P., Mori, H., and Okada, H. (2003).Elastic models for the magma intrusion associated with the 2000 eruption of Usu Volcano, Hokkaido, Japan. Journal of Volcanology and Geothermal Research, 125(1), 81-106.

Julian, B. R., and Sipkin, S. A. (1985).Earthquake processes in the Long Valley caldera area, California. Journal of Geophysical Research: Solid Earth (1978-2012), 90(B13), 11155-11169.

Kanamori, H., G. Ekström, G., A. Dziewonski, J. Barker, and S. Sipkin, (1993).Seismic radiation by magma injection: An anomalous seismic event near Tori Shima, Japan. Journal of Geophysical Research: Solid Earth (1978-2012), 98(B4), 6511-6522.

Kasahara, J., H. Katao, S. KOresawa, and M. Takahashi, Undersea seismic observation of 1989 volcanoseismic activity, off Ito, Izu Peninsula, central Japan. Journal of Physics of the Earth, 1991. 39(1): p. 107-130. 
Katili, J.A. and A. Sudradjat, The devastating 1983 eruption of Colo Volcano, Una-Una Island, central Sulawesi, Indonesia. Journal of Southeast Asian Earth Sci, 1990. 4(1): 82-82.

Kaufman, K. and L. Burdick (1980). The reproducing earthquakes of the Galapagos Islands. Bulletin of the Seismological Society of America 70(5): 1759-1770.

Kienle, J., et al., Ukinrek Maars, Alaska, April 1977 eruption sequence, petrology and tectonic setting.J. Volcanol. Geotherm. Res., 1980. 7(1-2): 11-37.

Klein, F. W., and Wright, T. (2008). Exponential decline of aftershocks of the M7. 91868 great Kau earthquake, Hawaii, through the 20th century. Journal of Geophysical Research: Solid Earth (19782012), 113(B9).

Koyaguchi, T., Volume estimation of tephra-fall deposits from the June 15, 1991, eruption of Mount Pinatubo by theoretical and geological methods. In: Newhall, C.G., Punongbayan, R.S. (Eds.), Fire and Mud; eruptions and lahars of Mount Pinatubo, Philippines, pp. 583-600.

Koyanagi, R.Y., Seismicity associated with volcanism in Hawaii; application to the 1984 eruption of Mauna Loa Volcano. Open-File Report - U. S. Geological Survey, 1987: 74-74.

Lahr, J. C., B. A. Chouet, C. D. Stephens, J. A. Power, and R. A. Page. Earthquake classification, location, and error analysis in a volcanic environment: implications for the magmatic system of the 19891990 eruptions at Redoubt Volcano, Alaska. J. Volcanol. Geotherm. Res. 62, no. 1 (1994): 137-151.

La Femina, P.C.,C.B. Conner, B.E. Hill, W. Strauch, and J.A. Saballos, Magma-tectonic interactions in Nicaragua: The 1999 seismic swarm and eruption of Cerro Negro volcano. J. Volcanol. Geotherm. Res., 2004. 137(1): 187-199.

Lange, D., A. Rietbrock, C. Haberland, K. Bataille, T. Dahm, F. Tilmann and E. Flüh, Seismicity and geometry of the south Chilean subduction zone (41.5 S-43.5 S): Implications for controlling parameters. Geophysical Research Letters (2007) 34(6).

Langbein, J., Dzurisin, D., Marshall, G., Stein, R., and Rundle, J. (1995). Shallow and peripheral volcanic sources of inflation revealed by modeling two-color geodimeter and leveling data from Long Valley caldera, California, 1988-1992. Journal of Geophysical Research: Solid Earth (1978-2012), 100(B7), 12487-12495.

Latter, J. (1976). Variations in stress release preceding and accompanying a submarine eruption in northern Tonga. Volcanism in Australasia: a collection of papers in honour of the late GAM Taylor: 355.

Leeds, D. J. (1974). Catalog of Nicaraguan earthquakes. Bulletin of the Seismological Society of America, 64(4), 1135-1158.

Legrand, D., A. Calahorrano, B. Guillier, L. Rivera, M. Ruiz, D. Villagomez, and H. Yepes,Stress tensor analysis of the 1998-1999 tectonic swarm of northern Quito related to the volcanic swarm of Guagua Pichincha volcano, Ecuador. Tectonophysics (2002) 344(1): 15-36.

Legrand, D., et al. (2011). The fluid-driven tectonic swarm of Aysen Fjord, Chile (2007) associated with two earthquakes ( $M w=6.1$ and $M w=6.2)$ within the Liquiñe-Ofqui Fault Zone. Continental Shelf Research 31(3): 154-161.

Lindsay, J.M., J.B. Shepherd, and D. Wilson, Volcanic and scientific activity at Kick 'em Jenny submarine volcano 2001-2002; implications for volcanic hazard in the southern Grenadines, Lesser Antilles. Natural Hazards, 2005. 34(1): 1-24.

Lockwood, J. P., J. J. Dvorak, T. T. English, R. Y. Koyanagi, A. T. Okamura, M. L. Summers, and W. R. Tanigawa, Mauna Loa 1974-1984; a decade of intrusive and extrusive activity. U. S. Geological Survey Professional Paper, 1987: 537-570.

Lorca, E. (1976). Deceptions Island: Seismic activity prior to the eruption of 1967. In Proc. Symp. Andean and Antarctic volcanology problems: Naples, IAVCEI (Vol. 632, p. 645). 
Lu, Z., C. Wicks, J.A. Power, D. Dzurisin, (2000). Ground deformation associated with the March 1996 earthquake swarm at Akutan volcano, Alaska, revealed by satellite radar interferometry. Journal of Geophysical Research: Solid Earth (1978-2012) 105(B9): 21483-21495.

Lu, Z., C. Wicks, D. Dzurisin, J.A. Power, S.C. Moran, and W. Thatcher, (2002). Magmatic inflation at a dormant stratovolcano: 1996-1998 activity at Mount Peulik volcano, Alaska, revealed by satellite radar interferometry. Journal of Geophysical Research: Solid Earth (1978-2012) 107(B7): ETG 4-1ETG 4-13.

Lu, Z., Wicks Jr, C., Kwoun, O., Power, J. A., Dzurisin, D. (2005). Surface deformation associated with the March 1996 earthquake swarm at Akutan Island, Alaska, revealed by C-band ERS and L-band JERS radar interferometry. Canadian Journal of Remote Sensing, 31(1), 7-20.

Macdonald, G. A. and A. Alcaraz (1956). "Nuées ardentes of the 1948-1953 eruption of Hibok-Hibok." Bulletin of Volcanology 18(1): 169-178.

McGarr, A., Seismic Moments and Volume Changes; J. Geophys. Res. 81 (8), 1976. 1487-1494.

McGarr, A., C. F. Williams, S. Hickman and D. Oppenheimer; Can Earthquakes Induced by Deep Fluid Injection Projects Be Controlled or Limited? 2011. In AGU Fall Meeting Abstracts, \#S44B-04.

McGarr, A. Maximum magnitude earthquakes induced by fluid injection. Journal of Geophysical Research: Solid Earth (2014).

McNutt, Stephen R. Volcanic Seismology. Annual Rev. Earth Planet. Sci. 32 (2005): 461-491.

Miller, A.D., White, R.A., and others, 1997.Seismicity of the Soufriere Hills Volcano, Montserrat, July 1995 to mid-1997. Montserrat Volcano Observatory Open-File Report 97/24, Government of Montserrat, 160-p.

Miller, V.L., C.J. Ammon, B. Voight, and G. thompson. Precise Hypocenter Location of High-FrequencyOnset Earthquakes, During the Initial Stages of Activity at Soufriere Hills Volcano, Montserrat. 2006. In AGU Fall Meeting Abstracts p. 586.

Minakami, T., T. Ishikawa, and K. Yagi, The 1944 eruption of volcano Usu in Hokkaido, Japan; history and mechanism of formation of the new dome "Syowa-Sinzan".Bull. Volcanol., 1951. 11: 45-157.

Minakami, T., The 1962 eruption of Miyake-sima, one of the seven Izu islands, Japan. Bull. Volcanol., 1964. 27: 225-235.

Minson, S.E., Dreger, D.S., Bürgmann, R., Kanamori, H., and Larson, K.M. (2007). Seismically and geodetically determined non-double-couple source mechanisms from the 2000 Miyakejima volcanic earthquake swarm. Journal of Geophysical Research: Solid Earth (1978-2012), 112(B10).

Moran, S.C., S.D. Stihler, and J.A. Power, A tectonic earthquake sequence preceding the April-May 1999 eruption of Shishaldin Volcano, Alaska. Bull. Volcanol., 2002. 64(8): 520-524.

Murase, M., T. Ito, Y. Hayashi, T. Sagiya, F. Kimata, and H. Watanabe, Spatio-temporal distribution of magma intrusions inducing repeated earthquake swarms off the east coast of the lzu Peninsula, central Japan, for 1973-1998.J. Volcanol. Geotherm. Res., 2010. 193(1-2): 25-36.

Nakada, S. and T. Druitt, The 2000 eruption of Miyakejima Volcano, Japan. Bull. Volcanol., 2005. 67(3): 203-280.

Nakada, S., H. Shimizu, and K. Ohta, Overview of the 1990-1995 eruption at Unzen Volcano. J. Volcanol. Geotherm. Res., 1999. 89(1-4): 1-22.

Nakamura, K. and T. Ui, Possible role of pore pressure in 1974 volcanic earthquakes of Chokai Volcano. Kasan = Bulletin of the Volcanological Society of Japan, 1975. 20, Second Series(2): 103-104.

Naranjo S., J.A., H. Moreno.R., and N.G. Banks La Erupcion del Volcano Hudson en 1991 (46 S) Region XI, Aisen, Chile 1991, Servicio Nacional de Geologia y Mineria (Temuco, Chile): Chile. p. 91.

Newhall, C. and D. Dzurisin, Historical unrest at large calderas of the world: USGS Bulletin, v. 1855. 1988. 
Nunez Cornu, F., F.A. Nava, S. De La Cruz-Reyna, Z. Jiminez, C. Valencia, and R. Garcia-Arthur, Seismic activity related to the 1991 eruption of Colima Volcano, Mexico.Bull. Volcanol., 1994. 56(3): 228237.

Ohtake, M. (1974), Seismic activity induced by water injection at Matsushiro, Japan. J. Phys. Earth 22, 163-176.

Ohtake, M. (1976). A review of the Matsushiro earthquake swarm. Kagaku 46: 306-313.

Okada, H. and Anonymous, Four recent dome-building eruptions at Mt. Usu and progress of mitigating volcanic hazards in 20th century. International Union of Geodesy and Geophysics General Assembly = Union Geodesique et Geophysique Internationale Comptes Rendus de la ...Assemblee Generale, 2003. 2003, Week 1: A.159.

Okada, Y. and E. Yamamoto, Dyke intrusion model for the 1989 seismovolcanic activity off Ito, central Japan. J. Geophy. Res.-solid Earth, 1991. 96(B6): 10361-10376.

Omori, F. (1911). The Usu-san eruption and earthquake and elevation phenomena. Bull. Imp. Earthq. Inv. Com., 5, 1-38.

Omore, F. (1928). On the Shimabara Earthquake of Dec. 8, 1922. Bulletin of the Imperial Earthquake Investigation Committee., 10(2), 43.

Onizawa, S.Y, H. Oshima, H.Y. Mori, T., Maekawa, A. Suzuki, M. Ichiyanagi, and H. Okada, Precursory earthquake hypocenters of the 2000 eruption of Usu Volcano, Japan, determined for the threedimensional velocity structure. International Union of Geodesy and Geophysics General Assembly = Union Geodesique et Geophysique Internationale Comptes Rendus de la ...Assemblee Generale, 2003. 2003, Week 1: 1-A547.

Panning, M., Dreger, D., and Tkalcic, H. (2001). Near-source velocity structure and isotropic moment tensors: A case study of the Long Valley Caldera. Geophysical Research Letters, 28, 1815-1818.

Pavlov, V., Levin, V., Maguskin, M., and Kasahara, M., Volcano-seismic crisis of January 1-2, 1996. Karymsky volcanic center (Kamchatka): elastic modeling of geodetic observations. XXIII General Assembly of IUGG, Sapporo, Japan. Abstracts A P. A, (2003). p. 555.

Pelton, J. R. and R. Smith (1982). Contemporary vertical surface displacements in Yellowstone National Park. Journal of Geophysical Research: Solid Earth (1978-2012) 87(B4): 2745-2761.

Power, J., Seismicity associated with the 1986 eruption of Augustine Volcano, Alaska: Fairbanks, University of Alaska. 1988, MS thesis, 142 p.

Power, J. A., Murray, T. L., Marso, J. N., and Laguerta, E. P. (1996). Preliminary observations of seismicity at Mount Pinatubo by use of the seismic spectral amplitude measurement (SSAM) system, May 13-June 18, 1991. Fire and Mud: Eruptions and Lahars of Mount Pinatubo, Philippines, Philippine Institute of Volcanology and Seismology, Quezon City, and University of Washington Press, Seattle, 269-283.

Power, J.A. and D.J. Lalla, Seismic observations of Augustine Volcano, 1970-2007. U. S. Geological Survey Professional Paper, 2010: 3-40.

Pozgay, S.H., R.A. White, D.A. Wiens, P.J. shore, A.W. Sauter, and J.L. Kaipat, Seismicity and tilt associated with the 2003 Anatahan eruption sequence. J. Volcanol. Geotherm. Res., 2005. 146(13): 60-76.

Roman, D. C., et al. (2004). "Evidence for dike emplacement beneath Iliamna Volcano, Alaska in 1996." J. Volcanol. Geotherm. Res. 130(3): 265-284.

Roman, D.C., S. de Angelis, J. Latchman and R. White, Patterns of volcanotectonic seismicity and stress during the ongoing eruption of the Soufriere Hills Volcano, Montserrat (1995-2007). J. Volcanol. Geotherm. Res., 2008. 173(3-4): 230-244. 
Rowe, C. A., C. H. Thurber, and R. A. White. "Dome growth behavior at Soufriere Hills Volcano, Montserrat, revealed by relocation of volcanic event swarms, 1995-1996." J. Volcanol. Geotherm. Res. 134.3 (2004): 199-221.

Ruppert, N.A., S. Prejean, and R.A. Hansen, Seismic swarm associated with the 2008 eruption of Kasatochi Volcano, Alaska: Earthquake locations and source parameters. J. Geophys. Res.-Solid Earth, 2011. 116.

Rymer, H., Cassidy, J., Locke, C. A., Barboza, M. V., Barquero, J., Brenes, J., and Van der Laat, R. (2000). Geophysical studies of the recent 15-year eruptive cycle at Poas Volcano, Costa Rica. J. Volcanol. Geotherm. Res., 97(1), 425-442.

Sabit, J.P., R.C. Pigtain, and E.G. de la Cruz, The west-side story: Observations of the 1991 Mount Pinatubo eruptions from the west.In: Newhall, C.G., Punongbayan, R.S. (Eds.), Fire and Mud; eruptions and lahars of Mount Pinatubo, Philippines, pp. 445-455.

Sibson, Richard H. Structural permeability of fluid-driven fault-fracture meshes. Journal of Structural Geology 18.8 (1996): 1031-1042.

Siebert, L., Simkin, T., and Kimberly, P., 2010, Volcanoes of the World, 3rd ed. Berkeley: University of California Press, 568 p.

Stuart, W. D. and M. J. Johnston (1975).Intrusive origin of the Matsushiro earthquake swarm. Geology 3(2): 63-67.

Sudo, Y., H. Ono, A.W. Hurst, T. Tsutsui, T., Mori, M. Nakaboh, Y. Matsumoto and S. Kikuchi,Seismic activity and ground deformation associated with 1995 phreatic eruption of Kuju Volcano, Kyushu, Japan. J. Volcanol. Geotherm. Res.. 1998. 81(3): 245-267.

Suzuki, S., H. Yamashita, H. Watanabe, Hm. Okada, and Y. Nishida, Hypocenters of the premonitory earthquakes to the 1977 eruption of Usu Volcano. Kasan = Bulletin of the Volcanological Society of Japan, 1980. 25(3): 181-193.

Thorarinsson, S. and G. Sigvaldason (1962). "The eruption in Askja, 1961; a preliminary report." American Journal of Science 260(9): 641-651.

Tilling, R. I., Rhodes, J. M., Sparks, J. W., Lockwood, J. P., and Lipman, P. W. (1987). Disruption of the Mauna Loa magma system by the 1868 Hawaiian earthquake: Geochemical evidence. Science, 235(4785), 196-199.

Tokarev, P.I., (1966). Izverzheniya i seismicheskii rezhim vulkanov Klyuchevskoi gruppy (Eruptions and Seismicity in the Klyuchevskoi Volcanic Cluster).

Tokarev, P.I., (1978). Prediction and characteristics of the 1975 eruption of Tolbachik Volcano, Kamchatka. Bull. Volcanol. 41(3): 251-258.

Tsuya, H. (1955). "Geological and Petrological Studies of Volcano, Fuji, V.: 5. On the 1707 eruption of Volcano Fuji." in Repository.dl.itc. at University of Tokyo

Uhira, K., T. Baba, H. Mori, H. katayama and N. Hamada, Earthquake swarms preceding the 2000 eruption of Miyakejima Volcano, Japan. Bull. Volcanol., 2005. 67(3): 219-230.

Ui, T., K. Nakamura, and K. Shibahashi, 1974 activity of Chokai Volcano, Japan. Bull. Volcanol., 1977. 40: 231-238.

Umakoshi, K., H. Shimizu, and N. Matsuwo, Volcano-tectonic seismicity at Unzen Volcano, Japan, 19851999. J. Volcanol. Geotherm. Res., 2001. 112(1-4): 117-131.

Valdés-González, C., and G.J. González-Pomposo, Determinación de etapas de comportamiento del volcán Popocatépetl, en base a su sismicidad. (1999) GEOS, 19, 305.

Villagomez, D.R., et al., Precursory seismic activity at Guagua Pichincha Volcano, Ecuador; implications for the magmatic system of an arc volcano. Eos, Transactions, American Geophysical Union, 2003. 84(46, Suppl.): Abstract V31B-04. 
Waite, G. P. and R. B. Smith (2002). Seismic evidence for fluid migration accompanying subsidence of the Yellowstone caldera. Journal of Geophysical Research 107(B9): 2177.

White, R. A., Distal Volcano-Tectonic (dVT) earthquakes: a near-real-time monitor for magma intrusion. In Cities on Volcanoes 4 Conference, Quito, Ecuador; January 2006.

White, R.A., and J.A. Power, Distal Volcano-Tectonic Earthquakes (DVT's): Diagnosis and Use in Eruption Forecasting. In AGU Fall Meeting Abstracts 1 (2001): p. 0001.

White, R.A., and C. Rowe, Distal Volcano-Tectonic (dVT) earthquake sequences and their use in Eruption Forecasting: Seismological Research Letters 77 (2) 240, April 2006.

Wicks, C., White, R., Patia, H., Collins, C., Johnson, W., and H. Yarai, (2007). Surface deformation from ALOS interferometry related to the July 2006 seismic crisis and dike intrusion on central New Britain Island, Papua New Guinea. Eos Trans. AGU, 88, 52.

Wicks, C., J.C. de La Llera, L.E. Lara and J. Lowenstern, The role of dyking and fault control in the rapid onset of eruption at Chaiten volcano, Chile. Nature, 2011. 478(7369): p. 374.

Williams, S. N. and S. Self (1983). "The October 1902 plinian eruption of Santa Maria volcano, Guatemala." Journal of Volcanology and Geothermal Research 16(1): 33-56.

Wood, H.O., On the earthquakes of 1868 in Hawaii. Bulletin of the Seismological Society of America, 1914. 4: 169-203.

Wu, J.P, Y.H. Ming, H.R. Zhang, G.M. Liu, L.H. Fand, W. Su, and W.L. Wand. Earthquake swarm activity in Changbaishan Tianchi volcano. Chinese Journal of Geophysics 50, no. 4 (2007): 938-946.

Zamora-Camacho, A., J.M. Espindola, and G. Reyes-Davila, The 1997-1998 Activity of Volcan de Colima, Western Mexico: Some Aspects of the Associated Seismic Activity. Pure and Applied Geophysics, 2007. 164(1): 39-52.

Zobin, V. M. (1970). The mechanism of the volcanic earthquakes connected with the eruption of the volcano Sheveluch in November, 1964. Izv. AN USSR, Phys. Earth: 31-36. 

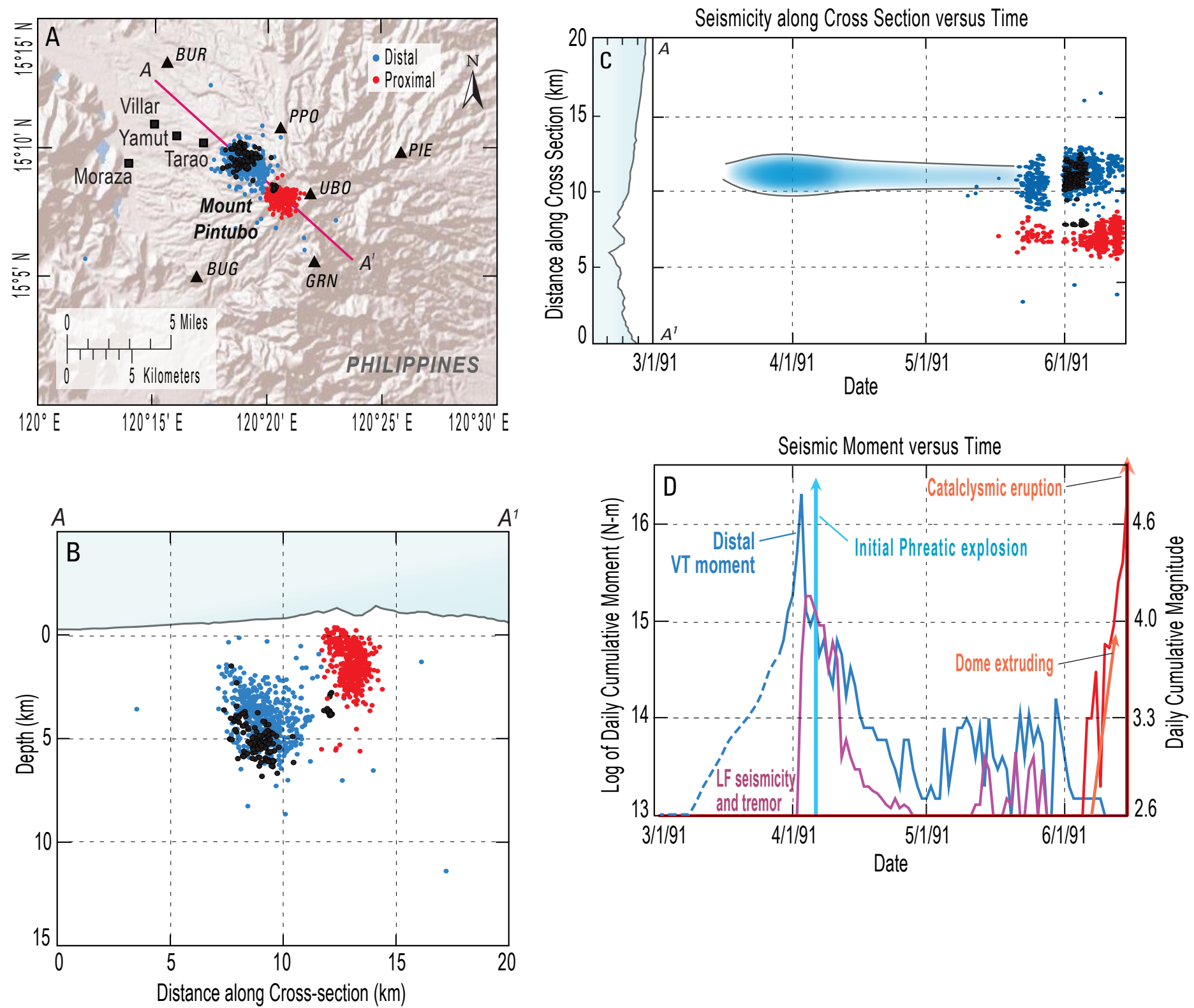

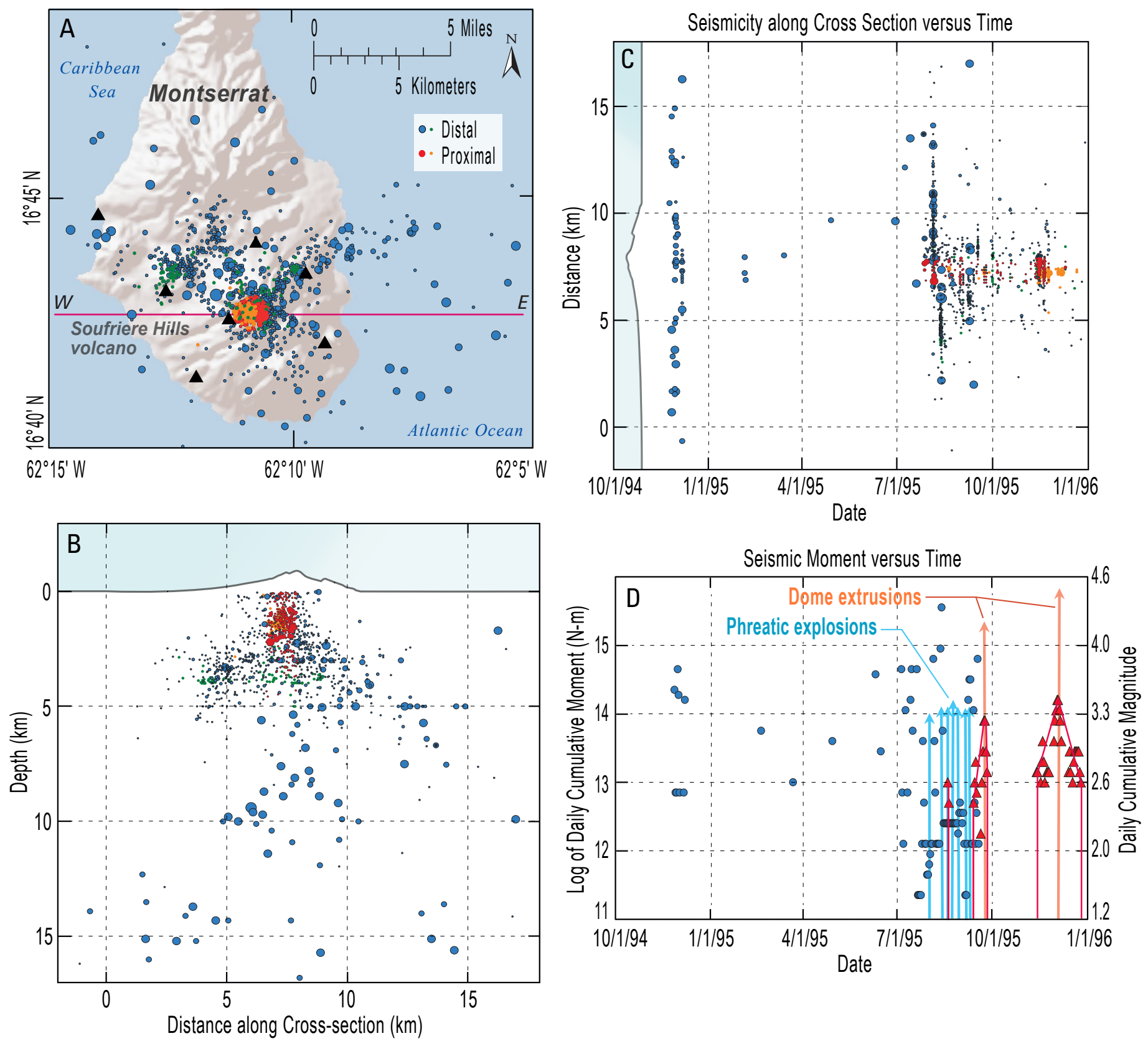


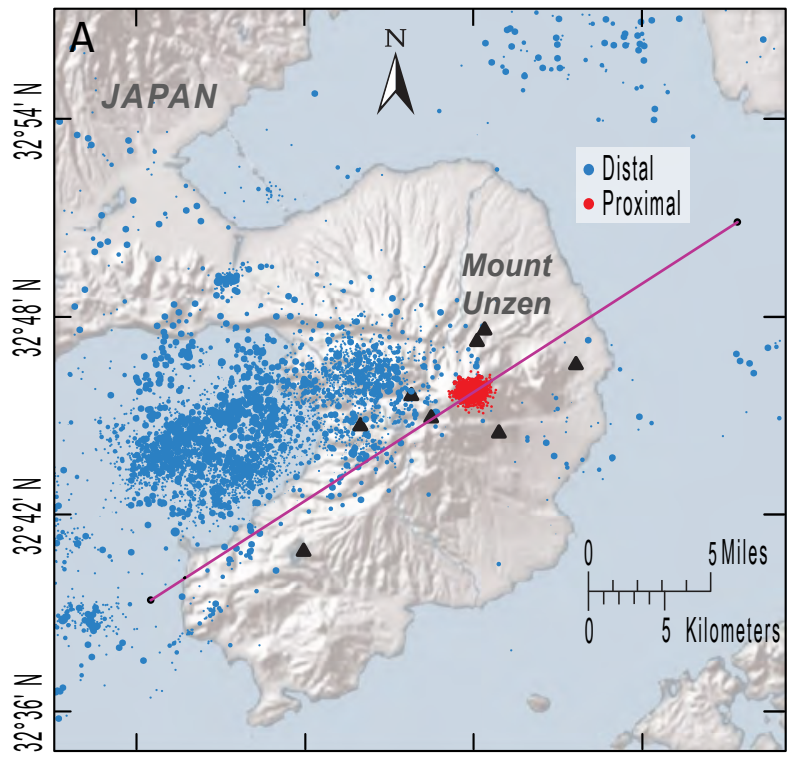

$130^{\circ} 6^{\prime} E \quad 130^{\circ} 12^{\prime} E \quad 130^{\circ} 18^{\prime} E \quad 130^{\circ} 24^{\prime} E$

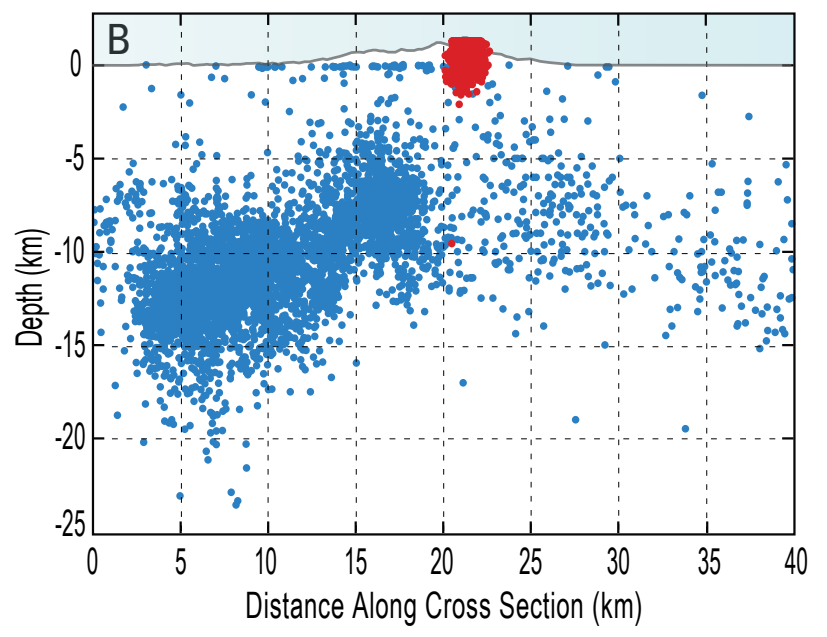

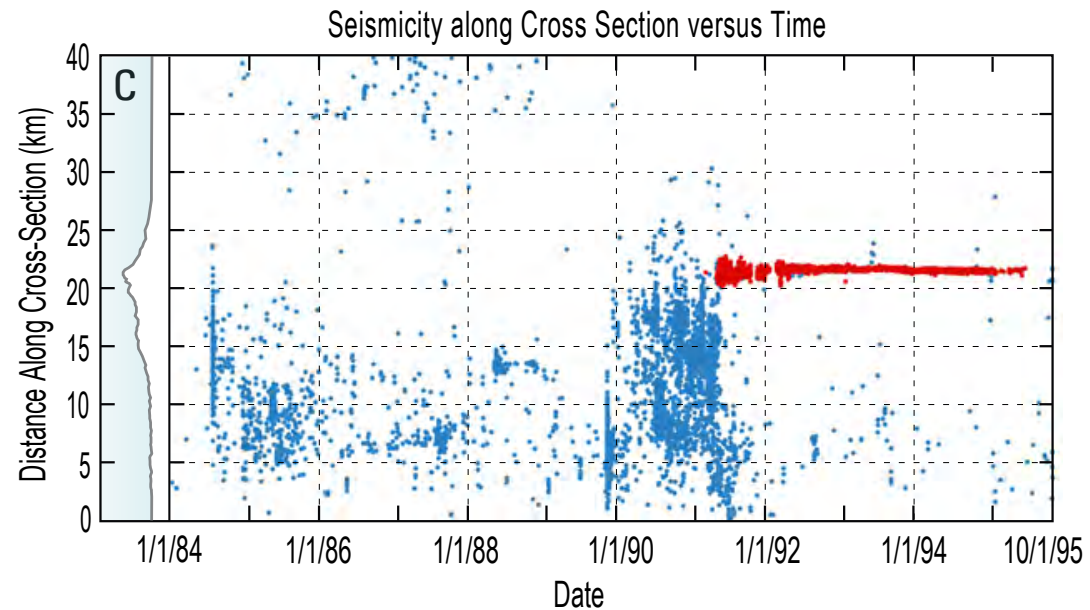

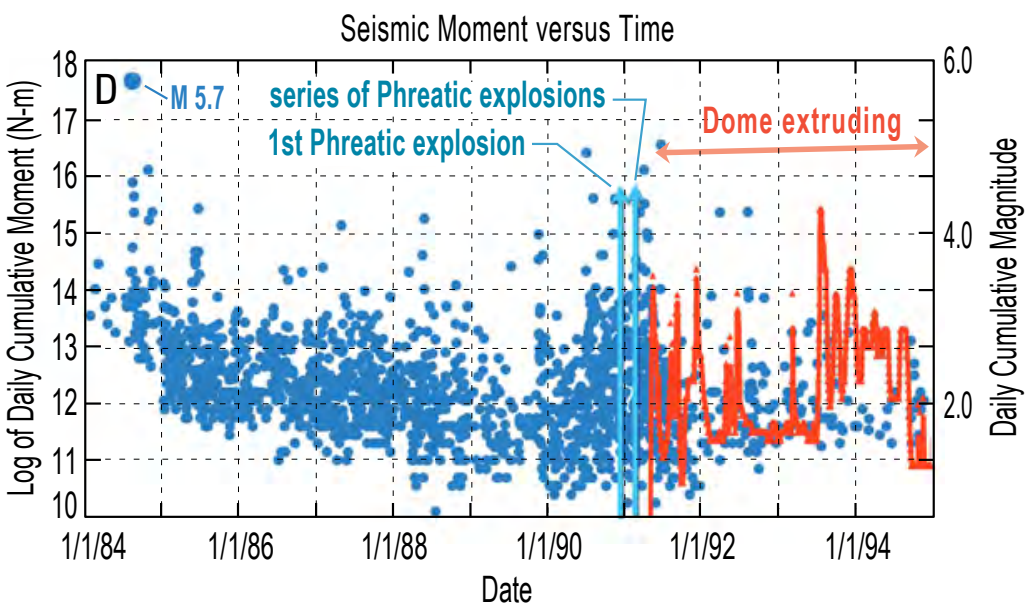



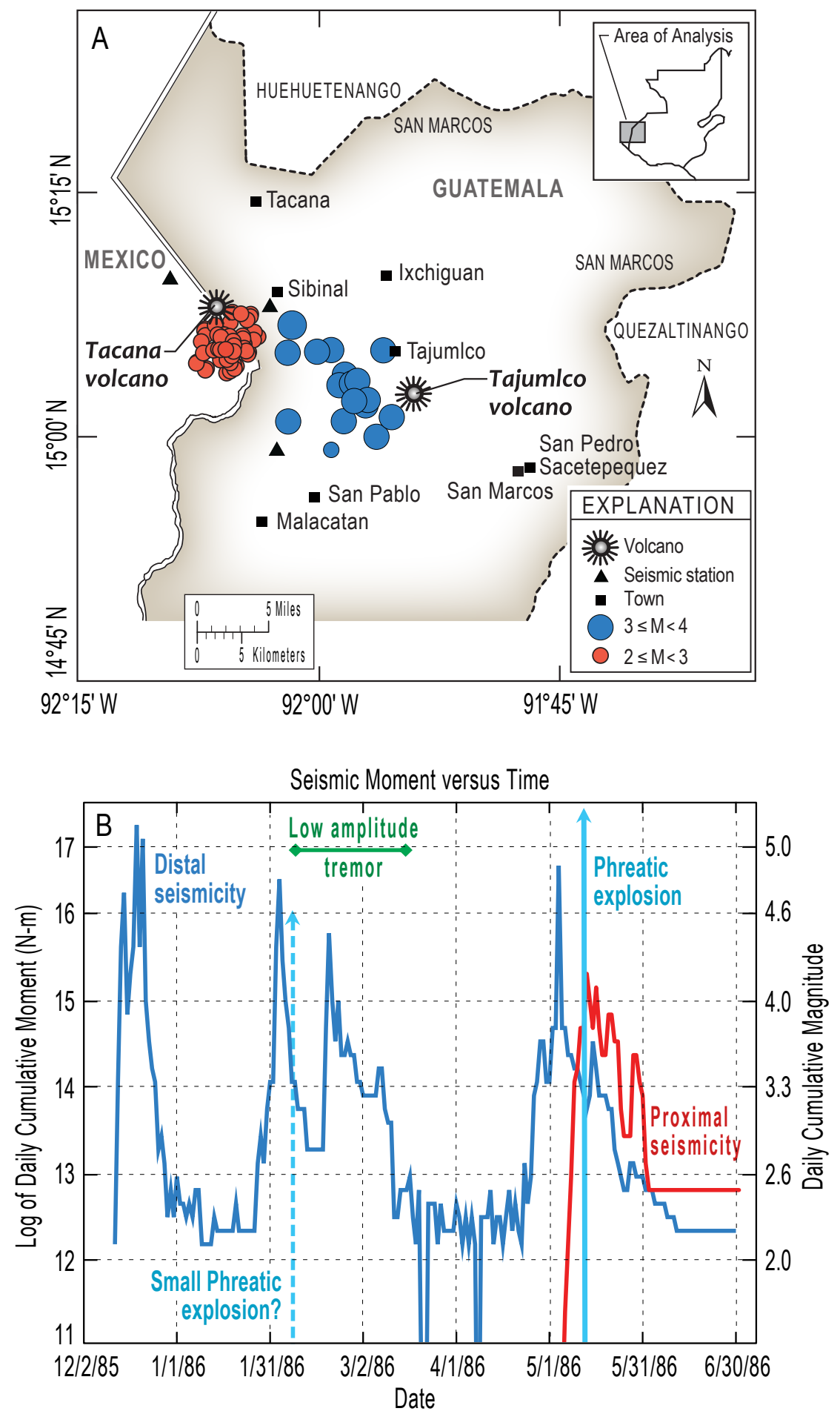


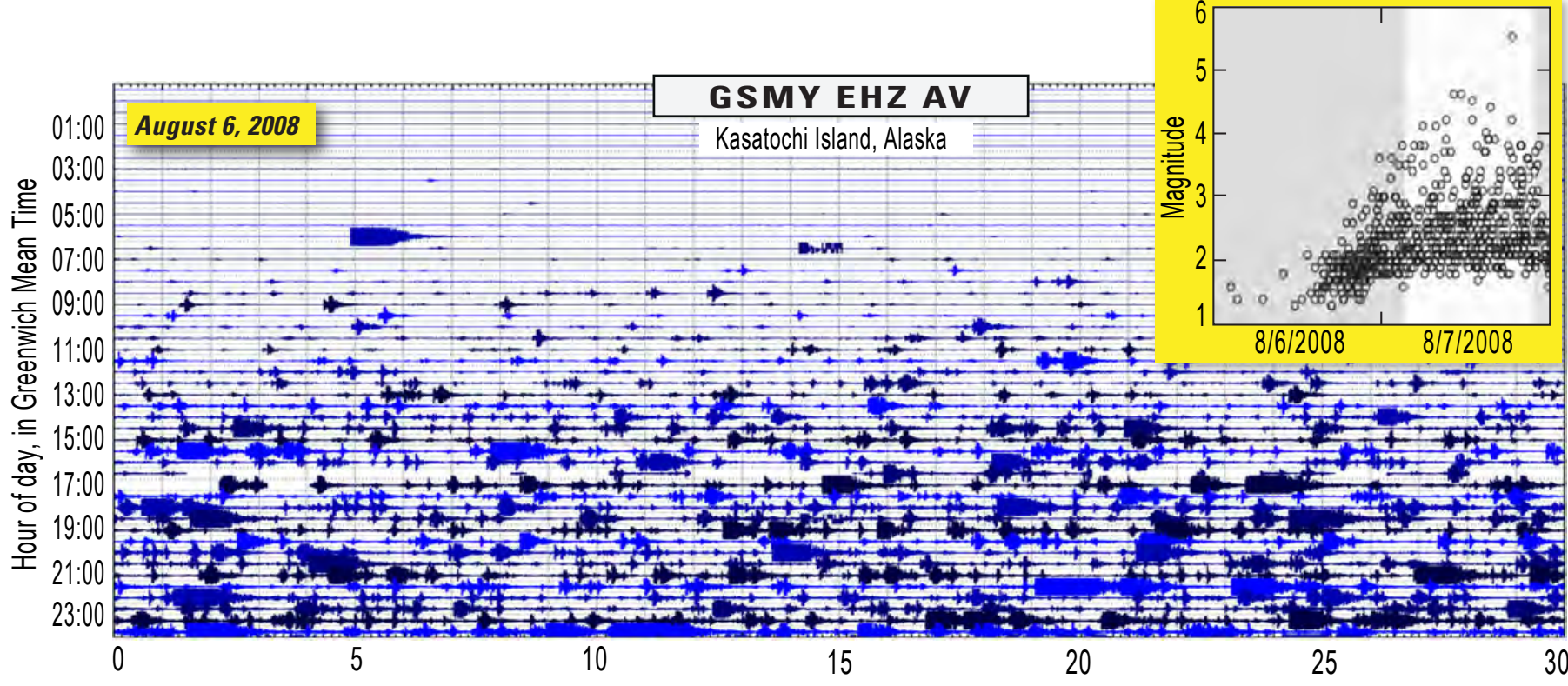

Time, in minutes

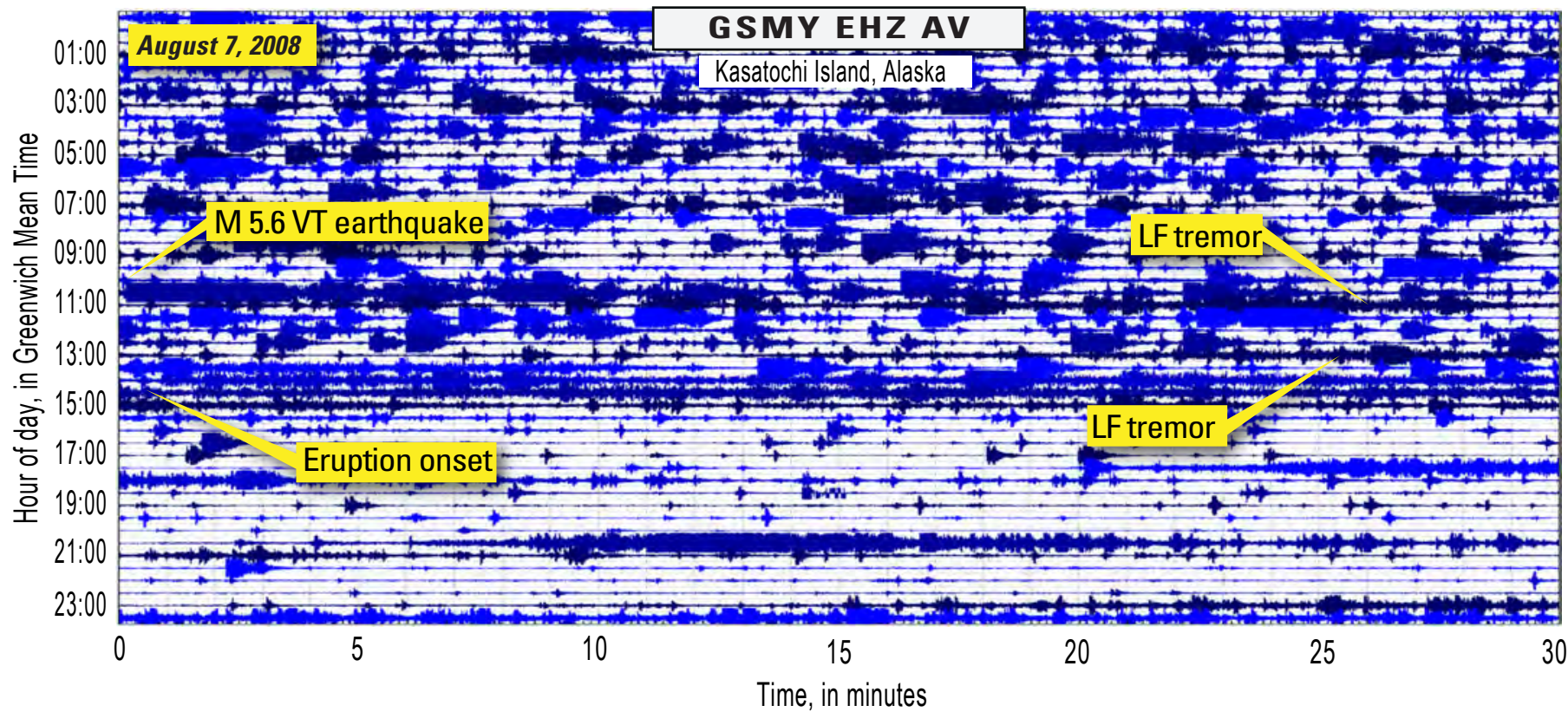




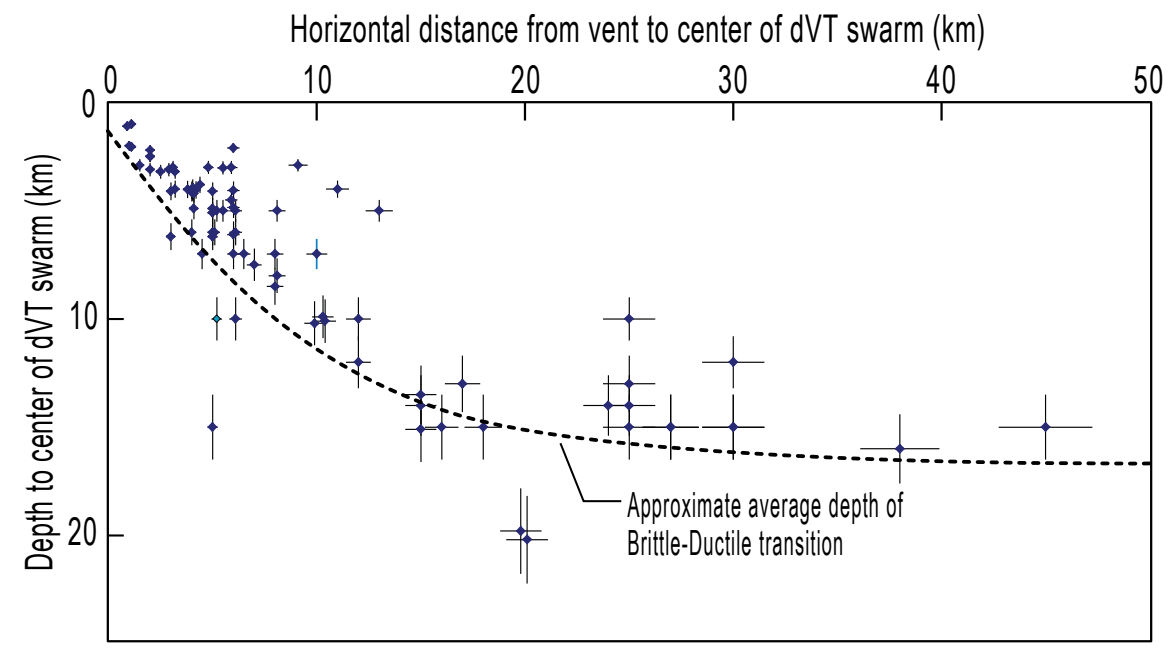




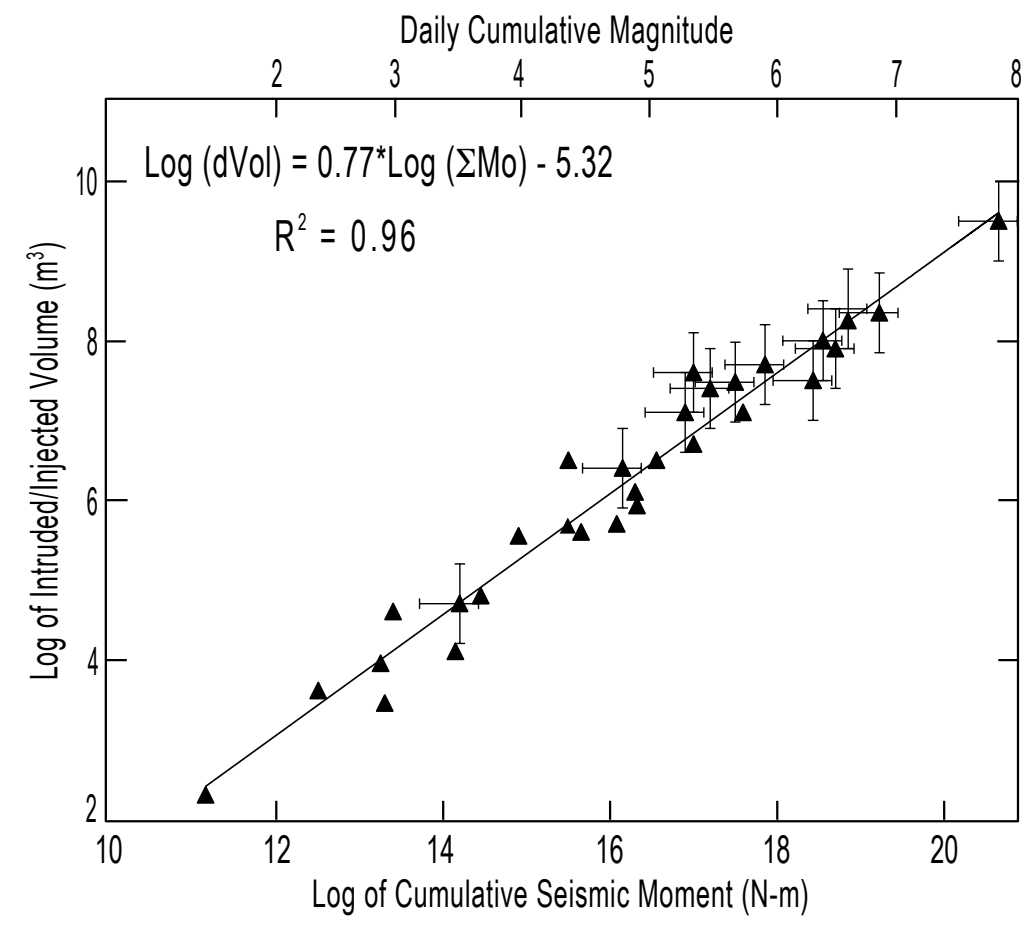



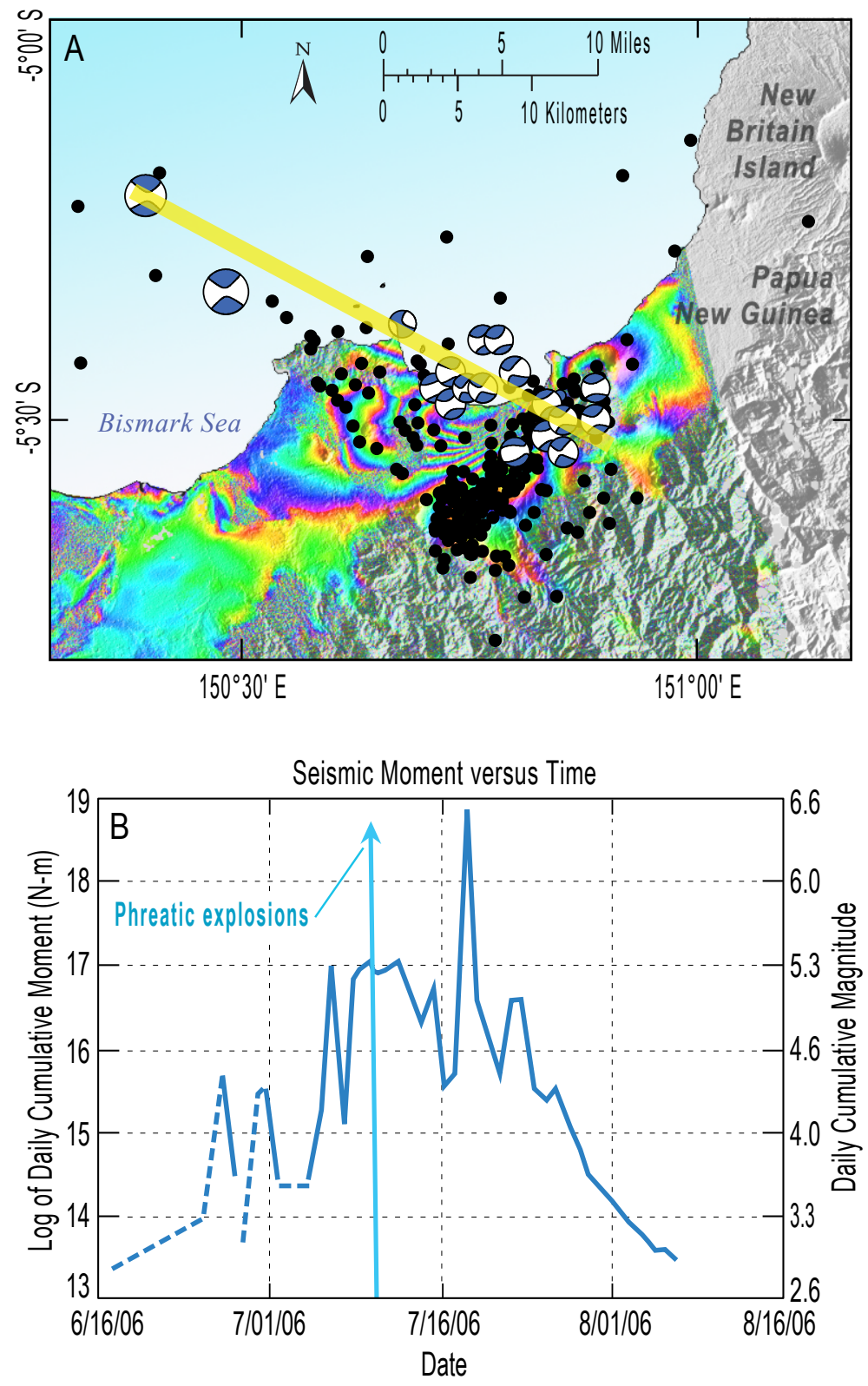